\title{
EL YACIMIENTO DE A DEVESA DE ABAIXO (PONTEVEDRA): MUERTE Y TRADICIÓN EN LA PREHISTORIA RECIENTE DEL NOROESTE DE LA PENÍNSULA IBÉRICA*
}

\author{
Pablo VÁzquez Liz \\ M. Pilar Prieto Martínez \\ Universidad de Santiago de Compostela
}

* Este trabajo se enmarca en el proyecto titulado «Estudio del cambio social en el III y II milenios BC en el NW de la península Ibérica a partir de yacimientos de contexto mixto» (HAR2012-34029), financiado al Plan Nacional de I+D+I 2008-2011 del Ministerio de Economía y Competitividad. Las 4 dataciones del Lab. de Upsala fueron financiadas por el LPPP-USC en 2010.

Copyright: (C) 2016 CSIC. Este es un artículo de acceso abierto distribuido bajo los términos de una licencia de uso y distribución Creative Commons Attribution (CC-by) España 3.0.

Cómo citar/Citation: Pablo VÁzquez Liz y M. Pilar Prieto Martínez, "El yacimiento de A Devesa de Abaixo (Pontevedra): muerte y tradición en la prehistoria reciente del Noroeste de la Península Ibérica”, Cuadernos de Estudios Gallegos, 63, núm. 129 (2016), págs. 13-64, DOI: http://dx.doi.org/10.3989/ceg.2016.129.01 


\section{EL YACIMIENTO DE A DEVESA DE ABAIXO (PONTEVEDRA): MUERTE Y TRADICIÓN EN LA PREHISTORIA RECIENTE DEL NOROESTE DE LA PENÍNSULA IBERICA}

\section{RESUMEN}

Se realiza la síntesis del yacimiento de A Devesa de Abaixo. El primer y único yacimiento al aire libre del Noroeste de la Península Ibérica que presenta un contexto funerario no tumular para el IV-V milenios BC. Nuestro objetivo es caracterizar el yacimiento y su secuencia de uso a lo largo del tiempo. La descripción del yacimiento de Os Torradoiros, localizado a escasos metros nos permitirá definir y completar esta caracterización. Los resultados radiocarbónicos son analizados y complementados por el estudio cerámico, que permite añadir información acerca de la actividad prehistórica no datada y se discute el yacimiento en una problemática general de los yacimientos al aire libre de la región.

PalABRAS ClaVE: Galicia, fosas, cistas, campaniforme regional gallego, neolítico, edad del bronce.

\section{O XACEMENTO DE A DEVESA DE ABAIXO (PONTEVEDRA): MORTE E TRADICIÓN NA PREHISTORIA RECENTE DO NOROESTE DA PENÍNSULA IBÉRICA}

RESUMO

Realízase a síntese do xacemento da Devesa de Abaixo. O primeiro e único xacemento ao aire libre do Noroeste da Península Ibérica que presenta un contexto funerario non tumular para o IV-V milenios BC. O noso obxectivo é caracterizar o xacemento e a súa secuencia de uso ao longo do tempo. A descrición do xacemento de Os Torradoiros, localizado a escass metros, permitiranos definir e completar esta caracyerización. Os resultados radiocarbónicos son analizados e complementados polo estudo cerámico, que permite engadir información acerca da actividade prehistórica non datada e discútese o xacemento nunha problemática xeral dos sitios ao aire libre da rexión.

Palabras ClaVE: Galicia, fosas, cistas, campaniforme rexional galego, neolítico, idade do bronce.

\section{A DEVESA DE ABAIXO ARCHAEOLOGICAL SITE (PONTEVEDRA): DEATH AND TRADITION IN LATE PREHISTORY IN THE NW OF THE IBERIAN PENINSULA}

\section{ABSTRACT}

We present a summary of the archaeological site of A Devesa de Abaixo, the first and only site in the NW Iberian Peninsula with a non-tumular funerary context from the fourth-fifth millennia $\mathrm{BC}$. The results of the radiocarbon datings are analysed and complemented by a pottery study, making it possible to add information about undated prehistoric activity. Next to A Devesa de Abaixo is placed Os Torradoiros site, its study allows us to complet the our knowledge about the chronological sequence in this area. The site is explored from the perspective of a problem that generally affects open-air sites in the region, and we contextualise the non-monumental funerary phenomenon in the NW Iberian Peninsula from the fifth to second millennia BC, comparing it with other European sites.

KeY words: Galicia, pits, cists, regional Galician Bell-Beaker, Neolithic, Bronze Age. 
Recibido/Received: 13/01/2016

Aceptado/Accepted: 27/06/2016

$\mathrm{E}$ $\mathrm{n}$ el presente trabajo abordaremos un conjunto de problemas arqueológicos del registro gallego de carácter general. Para ello, partiremos del estudio del yacimiento de A Devesa de Abaixo, y añadiremos el estudio del sitio de Os Torradoiros ${ }^{1}$, por haberse excavado simultánemente y aportar información complementaria, pues ambos estudios sirven como ejemplo para presentar los datos relacionados con esas problemáticas y comprender las soluciones aportadas. En primer lugar, trataremos las áreas de actividad al aire libre prehistóricos en Galicia. Esta introducción nos permitirá aclarar por qué seleccionamos el sitio de ADA-OTR como modelo para comprender algunos de los aspectos más importantes de este tipo de yacimientos. En segundo lugar, nos centraremos en el tipo de contexto, un conjunto de tumbas no-tumulares articuladas aparentemente por un único proyecto arquitectónico, espacial y de uso en el caso de ADA y un área de actividad doméstica en el caso de OTR. Si bien el tipo de contexto registrado en OTR es conocido en Galicia, la excepcionalidad de ADA en el registro gallego y las semejanzas con otras áreas de la Península y Europa hacen necesaria una publicación de detalle. En tercer lugar, trataremos de ordenar cronológicamente los contextos, pues se expondrán las 8 dataciones obtenidas para el yacimiento, que cubren de forma discontinua el período comprendido entre finales del $\mathrm{V}$ milenio

\footnotetext{
1 Para simplificar denominaremos en adelante ADA-OTR cuando tratemos de ambos yacimientos, o ADA, cuando nos refiramos a A Devesa de Abaixo y OTR cuando tratemos de Os Torradoiros exclusivamente. Pablo VÁzQuez Liz, Escavación arqueolóxica do xacemento de A Devesa de AbaixoGA36029002, San Pedro de Domaio, Moaña (Pontevedra), Santiago de Compostela, Memoria Técnica inédita, Consellería de Cultura e Xuventude, Xunta de Galicia, 2004; Pablo VÁzquez Liz, "Idade do Bronce: Devesa de Abaixo-Os Torradoiros", en Felipe Criado Boado y Elena Cabrejas Domínguez (coords.), Obras Públicas e Patrimonio: Estudo Arqueolóxico do Corredor do Morrazo, Madrid, Instituto de Estudos Galegos Padre Sarmiento, CSIC-Xunta de Galicia, 2005 (TAPA, 35), págs. 63-69; Pablo Vázquez Liz y M. Pilar Prieto Martínez, "Los yacimientos de A Devesa de Abaixo y Os Torradoiros: áreas de actividad campaniforme", en María Pilar Prieto Martínez y Laure Salanova (coords.), Las Comunidades Campaniformes en Galicia. Cambios sociales en el III y II milenios BC en el NW de la Península Ibérica, Pontevedra, Diputación de Pontevedra, 2011, págs. 211-225.
} 
y comienzos del II milenio BC, y su interpretación. Finalmente, se incorporará el estudio de los materiales cerámicos para completar algunos aspectos cronológicos del yacimiento, así como para comprender su funcionalidad a lo largo del tiempo y para resolver algunas cuestiones tipológicas al ponerlas en relación con su contexto y cronología. Se documentan nuevos tipos cerámicos que permiten ampliar el conocimiento sobre la cerámica de la zona.

Aunque el enterramiento bajo túmulo es el modelo funerario hegemónico en Galicia desde el V al III milenio BC, existen otras expresiones funerarias no necesariamente tumulares, cuya trascendencia en el registro funerario todavía está por calibrar, principalmente por su ocultación o invisibilidad en el paisaje, aunque su importancia se revela por la presencia y manipulación de un mobiliario variado, principalmente cerámico, relacionado con estas tumbas no monumentales. Por lo tanto, debemos extender el enfoque de estudio de los yacimientos al aire libre a la comprensión de lo funerario y no sólo lo doméstico o ceremonial. De este modo, nuestro primer objetivo es dar a conocer un yacimiento excepcional del noroeste de la Península Ibérica, ADA, y de forma complementaria OTR, pues nos sirve como modelo para plantear y aclarar problemas arqueológicos de interés general. El estudio estratigráfico y de materiales permitió caracterizar el yacimiento pero no establecer una cronología relativa firme porque los rasgos de las estructuras y los materiales son novedosos y difíciles de encajar en el registro arqueológico conocido de esta región de Iberia. La existencia de 8 dataciones, por su parte, ha permitido confirmar y asegurar la naturaleza de los yacimientos.

CARACTERÍSTICAS DE los YACIMIENTOS AL AIRE LiBRE GALlEGOS: UNA APROXIMACIÓN A SU PROBLEMÁTICA

Los yacimientos de ADA y OTR se inscriben dentro de los sitios arqueológicos de actividad al aire libre de la prehistoria reciente, cuya excavación es cada vez más frecuente en territorio gallego, y que poseen varios momentos de ocupación y en algún caso varios contextos funcionales, tanto en sentido sincrónico como diacrónico.

Las publicaciones de este tipo de yacimientos, en cambio, son excepcionales porque en la mayor parte de los casos su excavación es de tipo preventivo, vinculada generalmente a la ejecución de obras públicas de gran entidad, llegando en pocos casos a finalizarse las memorias técnicas, donde exponer e interpretar la información recuperada, por falta de financiación. Esta situación implica que el registro arqueológico documentado en este tipo de yacimientos apenas esté estudiado, y que en consecuencia no sean bien comprendidos. En líneas generales, se trata de sitios complejos a nivel estratigráfico, cronológico, funcional e incluso material. 
Desde un punto de vista estratigráfico, su rasgo definitorio es la ausencia de niveles arqueológicos verticales, con una estratigrafía horizontal originada por la dinámica natural postdeposicional que conforma una serie simple de dos o tres depósitos ${ }^{2}$, responsable de la desconexión estratigráfica entre las estructuras y los materiales, así como del desdibujado de las estructuras arqueológicas y de los niveles asociados a ellos ${ }^{3}$, siendo necesario realizar un gran número de análisis radiocarbónicos que en muchos casos contribuyen a ampliar el número de interrogantes más que a solventar las previamente planteadas. Por tal motivo, es necesario complementarlos con exámenes químicos de las muestras de los depósitos de colmatación de las estructuras y con el estudio de la distribución de los materiales ergológicos a nivel microespacial ${ }^{4}$, a fin de favorecer la definición diacrónica de la ocupación de los yacimientos, así como de sus procesos de formación.

Las propias dataciones radiocarbónicas también presentan su propia problemática, pues la acidez de los suelos gallegos impide la conservación de materia orgánica de origen animal, por lo que la práctica totalidad de las dataciones se efectúan sobre material vegetal, principalmente carbones procedentes de estructuras de combustión o de otro tipo y sedimento o residuos orgánicos extraídos de los depósitos de colmatación de estructuras negativas (fosas, zanjas, fosos, silos...) o de las paredes interiores de recipientes cerámicos. En este sentido, hay que ser consciente de que los carbones proceden, en muchos casos, de especies de existencia dilatada que a menudo ofrecen fechas envejecidas, que pueden retrasar artificialmente la datación de un episodio arqueológico concreto, caso del roble, especie muy utilizada en la prehistoria reciente, de acuerdo a los análisis antracológicos realizados en los últimos años ${ }^{5}$. Por ello es cada vez más frecuente realizar una identificación previa de las especies vegetales para seleccionar aquellas de vida más corta. La problemática aumenta en el caso de los análisis radiocarbónicos realizados a partir de sedimento porque los elementos orgánicos

\footnotetext{
2 Felipe Criado Boado y Antonio Martínez Cortizas, "O modelo de formación dun xacemento arqueolóxico", en Felipe Criado Boado y Elena Cabrejas Domínguez (coords.), Obras Públicas e Patrimonio: Estudo Arqueolóxico do Corredor do Morrazo, Madrid, Instituto de Estudos Galegos Padre Sarmiento, CSIC-Xunta de Galicia, 2005 (TAPA, 35), pág. 90.

3 Roberto Aboal Fernández, Xurxo Ayán Vila, Felipe Criado Boado, M. Pilar Prieto Martínez y Marta Tabarés Domínguez, "Yacimientos sin estratigrafía: Devesa do Rei, ¿un sitio cultual de la Prehistoria Reciente y la Protohistoria de Galicia?", Trabajos de Prehistoria, 62(2) (2005), pág. 166.

4 Roberto Aboal Fernández, Xurxo Ayán Vila, Felipe Criado Boado, M. Pilar Prieto Martínez y Marta TABARÉs Domínguez, "Yacimientos sin estratigrafía:...", pág. 166.

5 María Martín Seijo, Ana M.S. Bettencourt, Emilio Abad-Vidal y Juan Carlos López García, "Firewood and timber exploitation during the third and second millennia BC", in A. Campar de Almeida, Ana M.S. Bettencourt, D. Moura Sérgio Monteiro-Rodrigues y M. Isabel Caetano Alves the Northwestern Iberia: wooden resources, territories and chaîne opératoire, en (eds.), Environmental Changes and Human Interaction Along the Western Atlantic Edge, Coimbra, APEQ, CEGOT, CITCEM, CCT/CGUP, 2012, págs. 115-135.
} 
pueden ser anteriores o posteriores al episodio que se pretende fechar y su deposición en estructuras negativas puede corresponderse con una fase de abandono o con una constructiva ${ }^{6}$.

En Galicia han sido publicados hasta el momento ocho yacimientos que presentan información generalista y fechas de ${ }^{14} \mathrm{C}$ (Devesa do $\mathrm{Rei}^{7}$, Zarra de Xoacín $^{8}$, Carballeira do Espíritu Santo ${ }^{9}$, Montenegro, Os Remedios ${ }^{10}$ ), Setepías ${ }^{11}$, A Lagoa $^{12}$, Monte Buxel ${ }^{13}$ ) y otros cuatro parcialmente publicados con información radiocarbónica en algún caso (As Mamelas ${ }^{14}$, O Fuxiño ${ }^{15}$, As Cruces/Reborica ${ }^{16}$,

6 Ramón Fábregas Valcarce, Andrés Bonilla Rodríguez y Mario César Vila, Monte dos Remedios (Moaña, Pontevedra). Un asentamiento de la Prehistoria Reciente, Santiago de Compostela, Tórculo Edicións, 2007, pág. 35.

7 Roberto Aboal Fernández, Xurxo Ayán Vila, Felipe Criado Boado, M. Pilar Prieto Martínez y Marta TABArés Domínguez, "Yacimientos sin estratigrafía:..."; Marta TABARÉs Domínguez y M. Pilar Prieto Martínez, "Ceramic study of the Devesa do Rei archaeological site (Vedra, A Coruña, Spain)", in Maria Isabel Prudêncio; Maria Isabel Dias y Joâo Carlos Waerenborgh (eds.), Proceedings of the $7^{\text {th }}$ European Meeting on Ancient Ceramics- Understanding people through their pottery, Lisboa, Trabalhos de Arqueologia 42, 2005, págs. 271-276.

8 Roberto Aboal Fernández, Sofía Baqueiro Vidal, Virginia Castro Hierro, M. Pilar Prieto MarTínez y Marta TABArés Domínguez, "El yacimiento del III milenio BC de Zarra de Xoacín (Lalín, Pontevedra)", Lancia 6 (2004-2005), págs. 37-58.

9 Rebeca Blanco Rotea y M. Pilar Prieto Martínez, "Carballeira do Espíritu Santo: Un asentamiento aldeano de carácter familiar del Bronce Final", en M. Pilar Prieto Martínez y Felipe Criado Boado (coords.), Reconstruyendo la historia de la comarca del Ulla-Deza (Galicia, España). Escenarios arqueológicos del pasado, Madrid, Instituto de Estudos Galegos Padre Sarmiento, CSIC-Xunta de Galicia, 2010 (TAPA, 41), págs. 63-70.

10 Ramón Fábregas Valcarce, Andrés Bonilla Rodríguez y Mario César Vila, Monte dos Remedios...

11 Ángel Acuña Piñeiro, Víctor Barbeito Pose y M. Pilar Prieto Martínez, "Setepías (Cambados, Pontevedra), un ejemplo de arquitectura doméstica en la Edad del Bronce", en María Pilar Prieto Martínez y Laure Salanova (coords.), Las Comunidades Campaniformes en Galicia. Cambios sociales en el III y II milenios BC en el NW de la Península Ibérica, Pontevedra, Diputación de Pontevedra, 2011, págs. 13-24.

12 M. Pilar Prieto Martínez, "El área arqueológica de A Lagoa. La cerámica como expresión de división social", en María Pilar Prieto Martínez y Laure Salanova (coords.), Las Comunidades Campaniformes en Galicia. Cambios sociales en el III y II milenios BC en el NW de la Península Ibérica, Pontevedra, Diputación de Pontevedra, 2011, págs. 47-59.

13 Elena Lima Oliveira y M. Pilar Prieto Martínez, La Arqueología de la Gasificación de Galicia 16: Excavación del yacimiento de Monte Buxel, Santiago de Compostela, GIArPa, 2002 (TAPA, 27). 14 Juan CAno PAn, "El poblado de As Mamelas (Sanxenxo, Pontevedra)", en María Pilar Prieto Martínez y Laure Salanova (coords.), Las Comunidades Campaniformes en Galicia. Cambios sociales en el III y II milenios BC en el NW de la Península Ibérica, Pontevedra, Diputación de Pontevedra, 2011, págs. 193-200.

15 Miguel Vidal Lojo, “O Fuxiño: un asentamiento de la Edad del Bronce con campaniforme”, en María Pilar Prieto Martínez y Laure Salanova (coords.), Las Comunidades Campaniformes en Galicia. Cambios sociales en el III y II milenios BC en el NW de la Península Ibérica, Pontevedra, Diputación de Pontevedra, 2011, págs. 31-38.

16 Andrés Bonilla Rodríguez, "Asentamientos prehistóricos en As Cruces/Reborica (Aranga, A Coruña)”, en María Pilar Prieto Martínez y Laure Salanova (coords.), Las Comunidades Campaniformes 


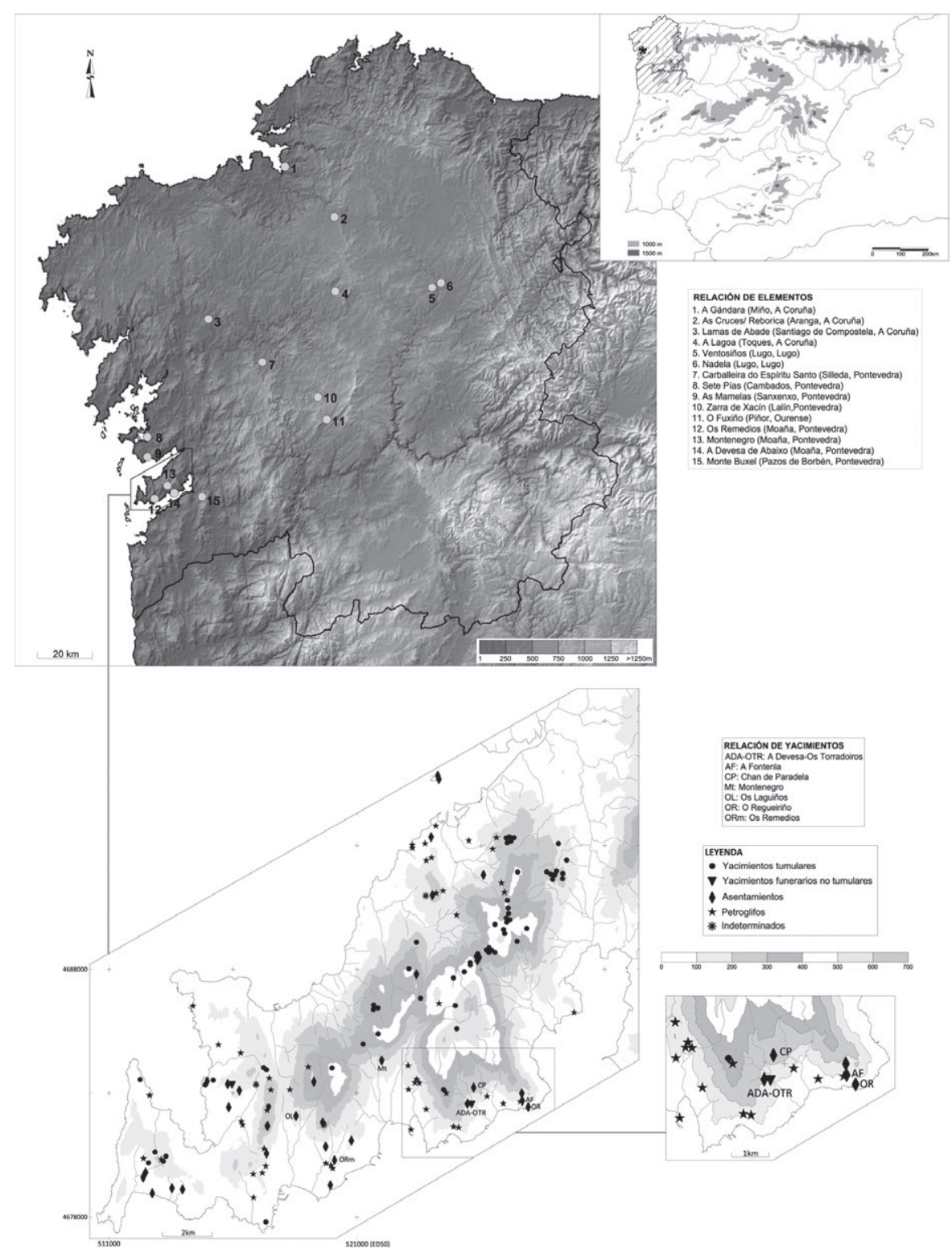

Figura 1. Localización del yacimiento de estudio y de otros yacimientos de la misma categoría en el contexto geográfico del NW hispánico. Distribución de yacimientos arqueológicos de la Prehistoria Reciente en el contexto geográfico de la península de O Morrazo, y localización de detalle del yacimiento de ADA-OTR y de los de su entorno. 
Chan das Pozas $^{17}$, Lamas de Abade $\left.^{18}\right)$, asimismo hay constancia de otros todavía inéditos (Nadela, Ventosiños, A Gándara o A Pataqueira) (Fig. 1).

Normalmente se trata de yacimientos claramente habitacionales articulados en torno a diferentes áreas de actividad como demuestran sus estructuras: fondos de cabaña de planta circular, curvilínea o excepcionalmente longhouses, estructuras de combustión con o sin elementos pétreos, agujeros de poste, zanjas de drenaje, zanjas para empalizadas, fosas de planta y profundidades diversas, silos..., a las que se asocia un amplio repertorio de materiales cerámicos y líticos. Pero en algunos casos se agregan otro tipo de estructuras de funcionalidad no doméstica, cuyo componente ritual o simbólico resulta en ocasiones bastante claro (recinto monumental de Montenegro, túmulo en Mamelas o estructuras de combustión pétreas de Zarra de Xoacín). De forma excepcional son documentados sitios arqueológicos de larga perduración y de funcionalidad funeraria y ritual exclusivamente (Devesa do Rei), aunque solamente en una de sus fases de uso, o funcionalidad funeraria asociada a una zona doméstica (As Mamelas). En este sentido, el yacimiento de ADA, se corresponde con el primer caso en la región de un contexto estrictamente funerario no tumular, de prolongada duración, incluidas las prácticas y ceremonias asociadas al mismo, desprovisto de cualquier connotación doméstica, y es coetáneo en sus primeras manifestaciones con el inicio de la actividad constructora de túmulos funerarios y su generalización.

En un nivel cronológico presentan una ocupación bastante definida que se puede concretar a lo largo de un milenio (Zarra de Xoacín), o bien limitarse a un período mucho más estrecho, de varios siglos (Carballeira do Espíritu Santo, O Fuxiño o Montenegro), aunque en algunos casos el comienzo de la actividad puede retrotraerse uno o dos milenios (Os Remedios, Devesa do Rei, A Lagoa). Esas ocupaciones más antiguas, del V y IV milenios $\mathrm{BC}$, responderían en los yacimientos plenamente domésticos a un asentamiento tipo campamento, normalmente con formas de habitación tenues (tiendas o pequeñas cabañas, hogueras y excepcio-

en Galicia. Cambios sociales en el III y II milenios BC en el $N W$ de la Península Ibérica, Pontevedra, Diputación de Pontevedra, 2011, págs. 25-30.

17 Andrés Bonilla Rodríguez y Mario César Vila, "Excavación de un posible yacimiento relacionado con los petroglifos en la zona de Chan das Pozas. Campaña de 2005", en Felipe Criado Boado, Antonio Martínez Cortizas y Marco V. García Quintela (coords.), Petroglifos, paleoambiente y paisaje. Estudios interdisciplinares del arte rupestre de Campo Lameiro, Pontevedra, Madrid, Incipit, CSIC, 2013 (TAPA, 42), págs, 124-129; Fidel Méndez Fernández y Jose López Alonso, "Excavación del yacimiento de Chan das Pozas. Campaña de 2008", en Felipe Criado Boado, Antonio Martínez Cortizas y Marco V. García Quintela (coords.), Petroglifos, paleoambiente y paisaje. Estudios interdisciplinares del arte rupestre de Campo Lameiro, Pontevedra, Madrid, Incipit, CSIC, 2013 (TAPA, 42), págs, 130-133.

${ }^{18}$ María Martín Seijo, Ana M.S. Bettencourt, Emilio Abad-Vidal y Juan Carlos López García, "Firewood and timber exploitation...". 
nalmente silos), que contrasta en gran medida con las asentamientos del III y II milenios BC, ya más estables, conformando verdaderos poblados (Os Remedios o Montenegro) o aldeas, establecimientos más discretos en dimensiones, como parece ocurrir a lo largo del II milenio (O Fuxiño, Carballeira do Espíritu Santo).

La propia correspondencia de ADA con un sitio al aire libre de estratigrafía horizontal, cuyas primeras evidencias quedan al descubierto una vez se produce remoción de tierras, alerta de la más que probable existencia de otros sitios funerarios no monumentales en el noroeste peninsular, de características similares, parecidas o completamente distintas, ocultos por las actuales condiciones de vegetación y edáficas del suelo. Por lo tanto, será nuestra intención en los siguientes apartados, desmenuzar los rasgos posicionales, estratigráficos y estructurales que definen el yacimiento, para a partir de los mismos, restituir su secuencia constructiva, material y cronológica.

\section{CONTEXTO GEOGRÁFICO Y ARQUEOLÓGICO}

ADA fue descubierto en 1981 por Antón Costa del Grupo Arqueolóxico do Morrazo dada la presencia de 5 piezas campaniformes en el interior/proximidad de dos pequeñas fosas abiertas en el terreno natural y con un relleno de tierra única ${ }^{19}$. Posteriormente fue incorporado en las investigaciones como un hallazgo campaniforme de la zona ${ }^{20}$ e integrado en el inventario de yacimientos arqueológicos de la administración autonómica como sitio indeterminado de la Edad del Bronce (código de identificación GA36029002).

Se localiza en la zona suroriental de la península do Morrazo (Fig. 1), en el SW del territorio gallego. En concreto, en la ladera oriental de la dorsal de estribación que con dirección predominante N-S, desciende desde el Monte Faro de Domaio, techo altitudinal de la península (628 m.s.n.m.) hasta la costa (ría de Vigo). Fisiográficamente se posiciona en un pequeño espolón o apéndice de dirección NE-SW (Fig. 2), en el tramo final de ladera, delimitado por el curso alto del rego da Freixa, que discurre a unos $115 \mathrm{~m}$ al E del yacimiento. A nivel geológico, se enclava en una estrecha banda de gneis granítico blastomilonítico, de dirección $\mathrm{N}-\mathrm{S}$, que se intercala entre una amplia zona de granitos de dos micas. El material geológico señalado es el utilizado en el acondicionamiento de todas las estructuras arqueológicas que conforman el yacimiento, lo que resulta obvio por la presencia de un afloramiento de ese material, a modo de crestón de dirección NO-SE que lo limita por el E. En cuanto al sector intervenido del yacimiento de OTR (Fig. 2),

\footnotetext{
19 José SuÁrez Otero, A Idade do Bronce en Galicia: Aspectos ceramolóxicos. O Bronce Inicial. Santiago de Compostela, Tesina de Licenciatura Inédita, Universidade de Santiago, 1986, pág. 50.

20 José SuÁrez Otero, A Idade do Bronce en Galicia..., págs. 50-51.
} 
situado a unos $156 \mathrm{~m}$ al S de ADA, se puede hacer extensiva la caracterización geográfica reseñada para aquel. Así, la zona de actuación se localiza en la ladera E de la misma dorsal de estribación que ADA, con la salvedad de que fisiográficamente se corresponde con la parte superior del tramo final de la ladera, con una caída bastante pronunciada en el sector E que se va suavizando hacia el SE, coincidiendo con la formación de una cabecera de vaguada.

Respecto al contexto arqueológico general del yacimiento, cabe destacar la profusión de sitios arqueológicos adscritos a la prehistoria reciente que presenta la Península do Morrazo (Fig. 1), principalmente túmulos, grabados rupestres y asentamientos, en particular de la transición del tercer al segundo milenio BC, identificados gracias a actividades prospectoras de particulares realizadas principalmente a finales de la década de los '70 y durante la de los ' 80 . En el caso de los asentamientos, la mayor parte de los datos provenían de la recuperación en superficie de conjuntos de materiales principalmente cerámicos, en los que sólo puntualmente se acometieron pequeñas excavaciones. En este sentido, la construcción del Corredor do Morrazo en el año 2003, favorece el descubrimiento y la excavación de nuevos asentamientos (Montenegro, Os Laguiños, Os Remedios) y contribuye a la correcta definición arqueológica de alguno de los ya conocidos (O Regueiriño, ADA). Los monumentos tumulares se distribuyen a lo largo de la parte alta de la dorsal que recorre longitudinalmente la península, en posición topográfica que contrasta con la de los asentamientos, que prefieren escalones o rellanos a media altura, pero próximos al litoral, en particular en la vertiente $\mathrm{S}$ de la península, al estar protegida de los vientos fríos del $\mathrm{N}$ y NE, con una ocupación casi continua. Los grabados rupestres, presentan un emplazamiento muy similar al de los asentamientos, situándose en varios casos en sus proximidades ${ }^{21}$.

\section{El yacimiento de A Devesa de Abaixo - Os Torradoiros}

En 2003, dentro del programa de corrección de impacto arqueológico originado por la construcción de la vía de alta capacidad denominada "Corredor de O Morrazo", se realizaron sondeos valorativos, dirigidos por uno de los autores de este trabajo (PVL) de la empresa Arqueoconsulting, que permitieron la identificación de dos zonas con evidencias arqueológicas claras (Fig. 2): una al $\mathrm{N}$ del sector conocido en el año 1981 como A Devesa de Abaixo (ADA) y otra al S de aquel denominado Os Torradoiros (OTR). Su excavación inmediata permitió la documentación íntegra del yacimiento de $\operatorname{ADA}\left(1.250 \mathrm{~m}^{2}\right)$, así como de un amplio sector del yacimiento de OTR $\left(850 \mathrm{~m}^{2}\right)$, en su práctica totalidad en posición secundaria.

\footnotetext{
$\overline{{ }^{21}}$ Para conocer más sobre este tema puede consultarse el siguiente trabajo: Antonio de la PEÑa SANTOS y Manuel Rey. "El espacio de la representación. El arte rupestre desde una perspectiva territorial" Revista de Estudos Provinciais, 10 (1993), págs. 11-50.
} 


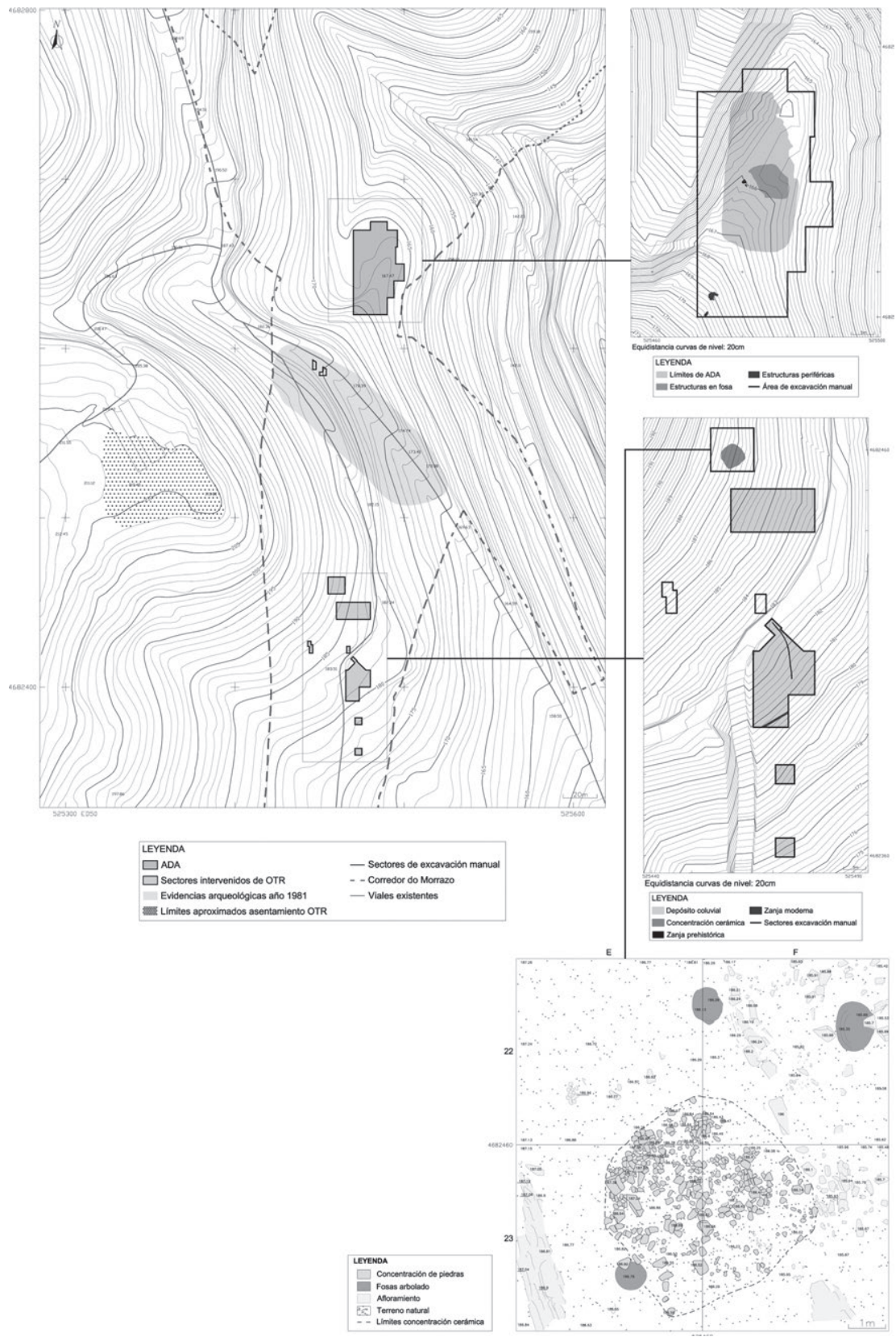

Figura 2. Topografía de detalle de ADA-OTR y entorno con los sectores de intervención arqueológica. Detalle del área de concentración cerámica de OTR. 
Fueron recuperadas 5.524 piezas, 3.934 fragmentos de cerámica (2.219 de ADA y 1.715 de OTR) y 1.590 líticos (1.066 de ADA y 524 de OTR). Es necesario recalcar que la zona de ocupación del yacimiento y su entorno circundante fue objeto de un intenso aprovechamiento forestal (eucaliptos principalmente), cuando menos desde época moderna (plantío de propiedad real), cuyos efectos incidieron negativamente en la conservación de ADA, ocasionando el desplazamiento de una buena parte de las piedras de revestimiento superior, principalmente hacia el W, dada la ausencia de barreras naturales que las contuvieran, así como una disgregación importante de las vasijas cerámicas o fragmentos de las mismas que fueron originariamente depositadas sobre aquella.

\section{ADA: Contextos, estructuras y su articulación espacial}

En ADA fueron identificadas 7 estructuras o grupos estratigráficos en posición primaria (Fig. 3): una cista con estela (ADA01), tres fosas a las que se les atribuye una funcionalidad funeraria (ADA03, ADA06 y ADA07), dos estructuras de combustión (ADA02 y ADA04) y una estructura lítica de finalidad imprecisa (ADA08), quizás de orden ritual. A excepción de esta última, la totalidad de estructuras se enclavan en la parte central del área de ocupación del yacimiento, aunque con una ligera desviación hacia el $\mathrm{E}$ y el $\mathrm{S}$, que precisamente es la que presenta a nivel fisiográfico la pendiente más suave de la totalidad del espolón en el que se dispone el sitio arqueológico. Es importante mencionar que la potencia que alcanza la secuencia estratigráfica que conforma el yacimiento es escasa, pues el espesor máximo en la zona donde se localizan las estructuras funerarias es de $40 \mathrm{~cm}$, a lo que se suman unos $30 \mathrm{~cm}$ de profundidad de las fosas en el terreno natural. En el resto del yacimiento la potencia es de $10-15 \mathrm{~cm}$.

A partir de la situación de las unidades estratigráficas de naturaleza arqueológica en el conjunto de la secuencia estratigráfica del yacimiento, se definen los

siguientes grupos de estructuras (Tabla 1): Estructuras de sellado y delimitación, estructuras en torno al área funeraria y estructuras en fosa que conforman la necrópolis o área funeraria.

Estructuras de sellado y delimitación: Son dos unidades estratigráficas.

- Capa de piedras de gneis granítico (UE1003) de diversos tamaños (10-20 $\mathrm{cm}$ de espesor) que funciona como un revestimiento superficial (Fig. 3: fotos). La disposición de las piedras sería regular en origen y están colocadas sobre el terreno natural en su mayor parte. Este revestimiento tiene forma casi elíptica en planta, adaptándose a la disposición del relieve, su eje N-S (35,6 m) es más desarrollado que el E-W $(13,30$ m). Proporcionó el $88 \%$ (1.902) de los materiales recuperados en el yacimiento, con cerámicas decoradas con distintos motivos, abundantes piezas líticas, predominando 


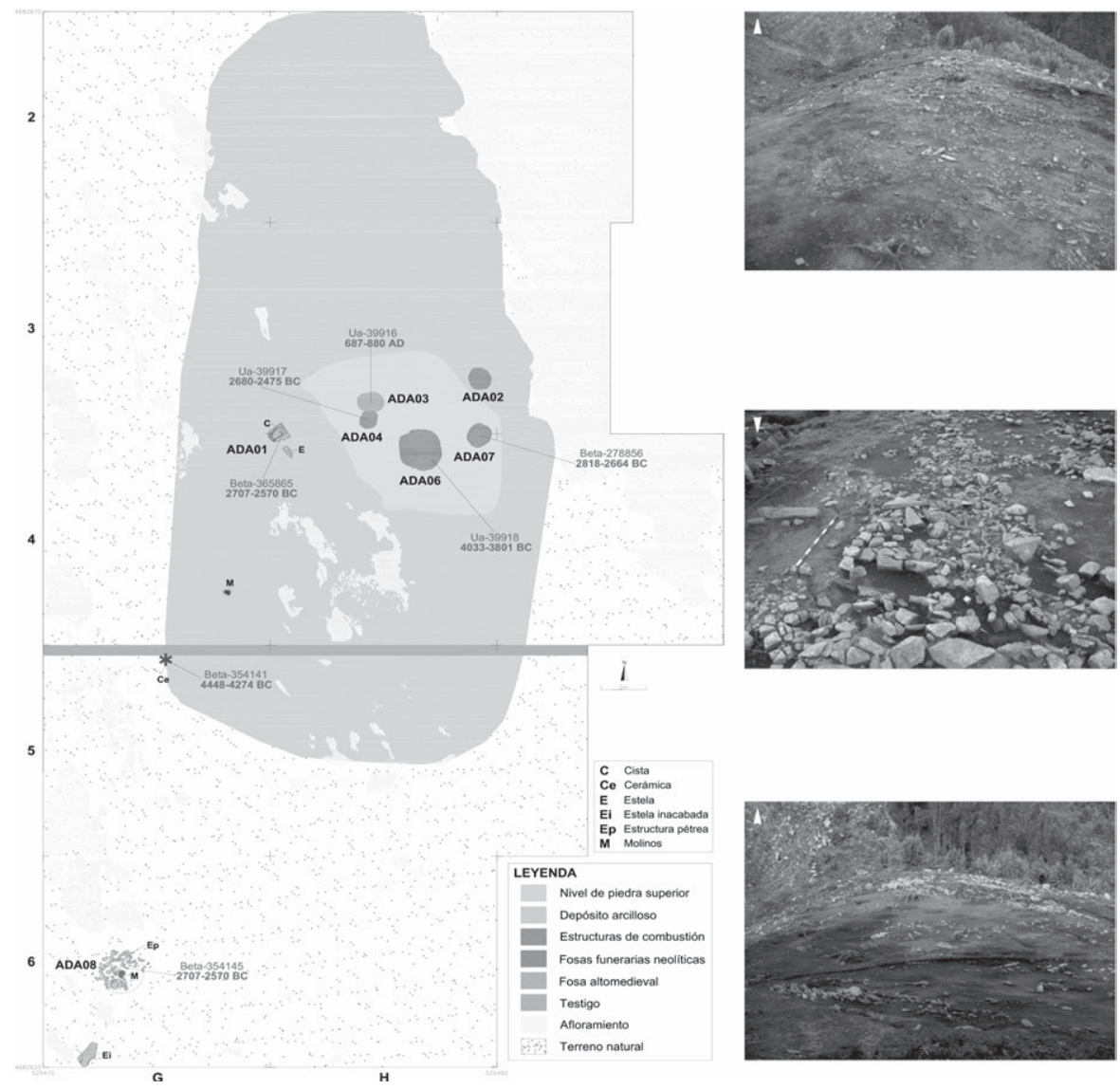

Figura 3. Planta esquemática del yacimiento de ADA con las estructuras arqueológicas que lo conforman y sus respectivas fechas radiocarbónicas calibradas. Fotografías de la capa de revestimiento superficial del yacimiento (imágenes superior e intermedia) y del área funeraria y entorno una vez retirada la referida capa pétrea (imagen inferior).

las lascas y los restos de talla en cuarzo, aunque también están presentes elementos amortizados del ámbito doméstico: molinos, fragmentos de hachas, microlitos, raspadores. Se localiza por debajo de la capa vegetal y se apoya en su mayor parte en el substrato, a excepción de la zona donde fueron acondicionadas las estructuras centrales en fosa, en la que descansa sobre un nivel de arcilla.

- Depósito de arcilla de 10-15 cm de espesor de planta irregular (UE1004) delimitado al $\mathrm{E}$ y al $\mathrm{W}$ por el afloramiento de la roca, de 7,55 $\mathrm{m}$ en el eje $\mathrm{N}-\mathrm{S}$ y de 7,30 m en el E-W. Este depósito está sellado por la capa lítica de 
Tabla 1. Síntesis estratigráfica del yacimiento de ADA

\begin{tabular}{|c|c|c|c|c|c|}
\hline $\begin{array}{c}\text { Unidades } \\
\text { arqueológicas }\end{array}$ & Estructura & Función & UES & Descripción & $\begin{array}{c}\text { Grupo } \\
\text { estructural }\end{array}$ \\
\hline \multirow{9}{*}{$\begin{array}{l}\text { SUPERIORES } \\
\text { (bajo la capa } \\
\text { vegetal) }\end{array}$} & ADA01 & & 06 & Lajas & \multirow{8}{*}{$\begin{array}{l}\text { En torno } \\
\text { al área } \\
\text { funeraria }\end{array}$} \\
\hline & $(55 \times 23-32 \times 41 \mathrm{~cm}$ & Cista inhumación & 07 & Relleno interior orgánico & \\
\hline & en el interior) & & 08 & Relleno interior arcilloso- arenoso & \\
\hline & & & 13 & Calzos & \\
\hline & & & 37 & Estela de señalización & \\
\hline & \multirow[t]{2}{*}{ ADA08 } & \multirow[t]{2}{*}{ Estructura lítica } & 35 & Capa de piedra con molino & \\
\hline & & & 36 & Nivel de tierra carbonizada & \\
\hline & Estela inacabada & Señalización? & 38 & Bloque de gneis granítico & \\
\hline & Capa lítica & $\begin{array}{l}\text { Revestimiento del área } \\
\text { funeraria y entorno }\end{array}$ & 03 & $\begin{array}{l}\text { Capa de piedra de } \\
\text { gneis granítico }\end{array}$ & \multirow[b]{2}{*}{$\begin{array}{c}\text { Selladoy } \\
\text { delimitación }\end{array}$} \\
\hline $\begin{array}{c}\text { INTERMEDIAS } \\
\text { (entre las } \\
\text { superiores e } \\
\text { inferiores) }\end{array}$ & $\begin{array}{l}\text { Depósito de } \\
\text { arcilla }\end{array}$ & Sellado área funeraria & 04 & Nivel de arcilla & \\
\hline \multirow{6}{*}{$\begin{array}{l}\text { INFERIORES } \\
\text { (las abiertas } \\
\text { en el substrato } \\
\text { y sus } \\
\text { respectivas } \\
\text { colmataciones) }\end{array}$} & ADA02 & Hogar NE & $\begin{array}{l}14 \\
15 \\
16\end{array}$ & $\begin{array}{l}\text { Depósito de piedras } \\
\text { Nivel de cenizas y carbones } \\
\text { Corte }\end{array}$ & $\begin{array}{l}\text { En torno } \\
\text { al área } \\
\text { funeraria }\end{array}$ \\
\hline & ADA03 & Estructura en caja & $\begin{array}{l}18 \\
19 \\
20\end{array}$ & $\begin{array}{l}\text { Depósito de piedras } \\
\text { Nivel de tierra carbonizada } \\
\text { Corte }\end{array}$ & \multirow{5}{*}{$\begin{array}{c}\text { Área } \\
\text { funeraria } \\
\text { de fosas }\end{array}$} \\
\hline & ADA04 & Hogar SW & $\begin{array}{l}22 \\
23 \\
24\end{array}$ & $\begin{array}{l}\text { Paravientos } \\
\text { Nivel de cenizas y carbones } \\
\text { Corte }\end{array}$ & \\
\hline & ADA06 & $\begin{array}{l}\text { Estructura de } \\
\text { inhumación }\end{array}$ & $\begin{array}{l}28 \\
29 \\
30 \\
31\end{array}$ & $\begin{array}{l}\text { Depósito de piedras } 1 \\
\text { Depósito de piedras } 2 \\
\text { Nivel de cenizas y carbones } \\
\text { Corte }\end{array}$ & \\
\hline & ADA07 & $\begin{array}{l}\text { Estructura de } \\
\text { inhumación }\end{array}$ & $\begin{array}{l}28 \\
30 \\
31\end{array}$ & $\begin{array}{l}\text { Depósito de piedras } \\
\text { Nivel de cenizas y carbones } \\
\text { Corte }\end{array}$ & \\
\hline & $\begin{array}{l}\text { Capa de piedras } \\
\text { discontinua }\end{array}$ & $\begin{array}{l}\text { Delimita el espacio } \\
\text { ocupado por las fosas }\end{array}$ & 05 & $\begin{array}{l}\text { Piedras colocadas sobre el } \\
\text { substrato y selladas por el } \\
\text { depósito intermedio arcilloso }\end{array}$ & \\
\hline
\end{tabular}


revestimiento y asentado en el terreno natural y sobre una capa de piedras irregular, en una ligera depresión de aquel en sentido E-W y sella a su vez a las dos estructuras funerarias en fosas (ADA06 y ADA07). Suministró 132 piezas entre cerámica y líticos (lascas), destacando la cerámica con decoración incisa.

Estructuras en torno al área funeraria: Son once unidades estratigráficas que conforman tres arquitecturas pétreas.

- Cista de pequeñas dimensiones (ADA01) (Fig. 4), integrada en la capa lítica, cortándola, aunque sobresaliendo unos $20 \mathrm{~cm}$, para hacerla destacar en el área, potenciando esta visibilidad la colocación a su lado de una estela de $60 \mathrm{~cm}$ de alto y forma cónica. Las lajas de la tumba se encontraban ligeramente hincadas en el terreno natural. En su interior fueron recuperadas 4 lascas en cuarzo.

- Hoguera (ADA02) (Fig. 5) bajo la capa lítica superior de revestimiento, que se compone de un nivel de cubrición de piedras (15-20 cm de espesor) sobre un lecho de carbones y cenizas, dispuesto en una suave fosa.

- Estructura pétrea exterior (ADA08) (Fig. 6) de planta circular y estela inacabada (UE1037) preparadas en el entorno SW de los límites fijados por la capa lítica de revestimiento. La estructura pétrea presenta un durmiente de molino completo integrado en la capa de piedras que cubre un nivel de carbones.

Área funeraria de fosas: Conformada por catorce unidades estratigráficas agrupadas en 4 estructuras tipo fosa de diferente función, delimitadas por una capa de piedras discontinua colocadas sobre el substrato que marcan el espacio ocupado por las fosas (UE1005).

- Tumbas (ADA06 y ADA07) (Figs. 7-8) de planta tendente a elíptica de más de $1 \mathrm{~m}$ de diámetro, integradas por tres unidades estratigráficas: una capa superior de piedras de $15-20 \mathrm{~cm}$ de espesor (que en un caso es doble: ADA07), un depósito inferior de cenizas y carbones y finalmente el corte de las fosas, de $30 \mathrm{~cm}$ profundidad. Sin ajuar. Ambas estructuras se encuentran selladas por el depósito de arcilla o UE1004.

- Estructura lítica (ADA03) (Fig. 9), de planta rectangular (70x60x27 cm en el exterior) a modo de caja, conformada por un nivel de piedras, sirviendo de cubierta la colocada al N. Se localiza bajo una capa orgánica y sobre un pequeño depósito de cenizas. Sin materiales.

- Hogar (ADA04) (Fig. 9) localizado por debajo de una capa orgánica de naturaleza postdeposicional, con un nivel de piedras limitado a la mitad $\mathrm{N}$ o paravientos bajo el que se dispone un depósito de carbón y cenizas. Sólo proporcionó una mano de molino integrada en la capa de piedra. 


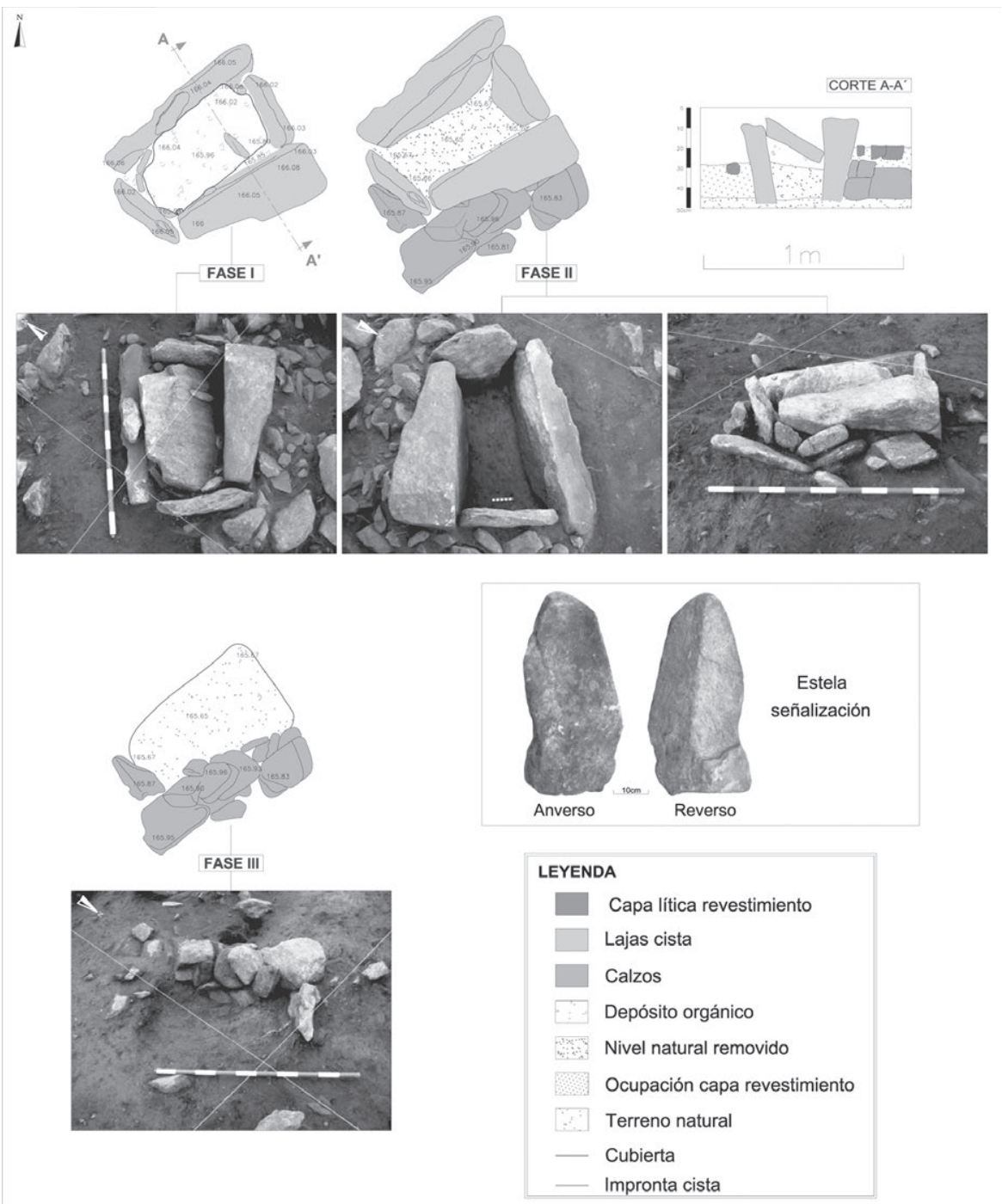

Figura 4. Cista ADA01. Fases de excavación y articulación estratigráfica ${ }^{22}$.

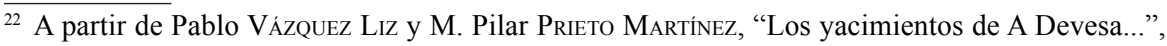
fig. 5, pág. 219.
} 

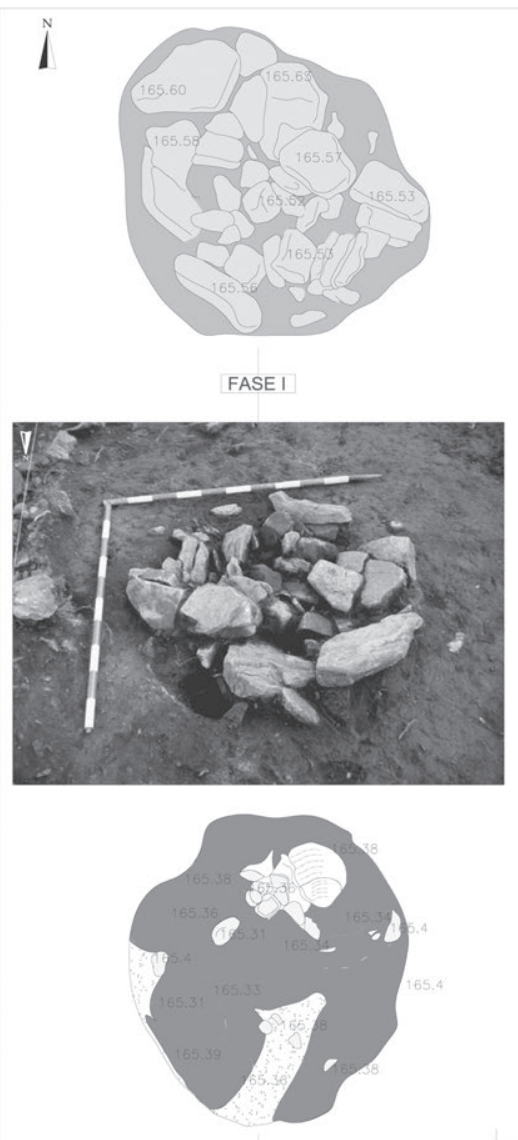

FASE III

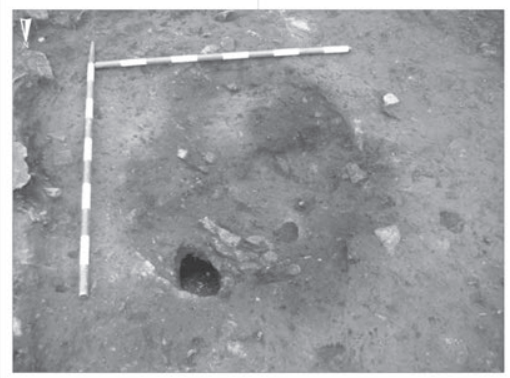

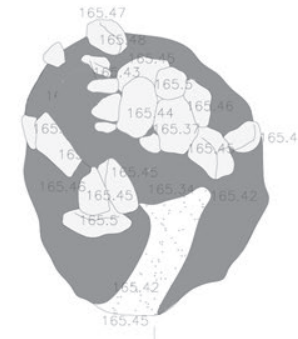

FASE II
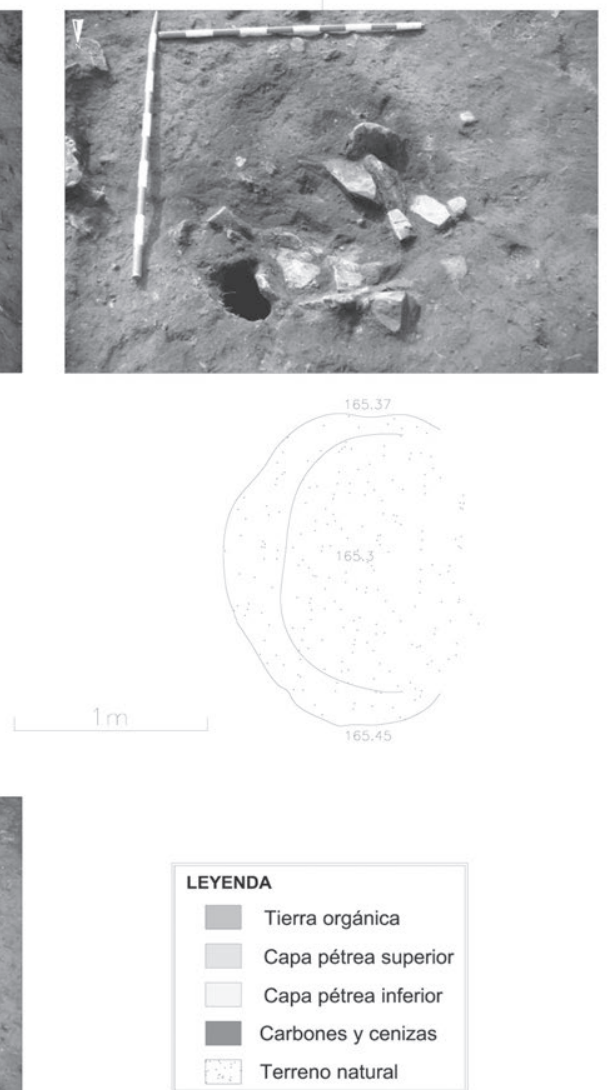

Figura 5. Hoguera ADA02. Fases de excavación y articulación estratigráfica ${ }^{23}$.

\footnotetext{
${ }^{23}$ A partir de Pablo VÁzquez Liz y M. Pilar Prieto Martínez, "Los yacimientos de A Devesa...”, fig. 5, pág. 219.
} 


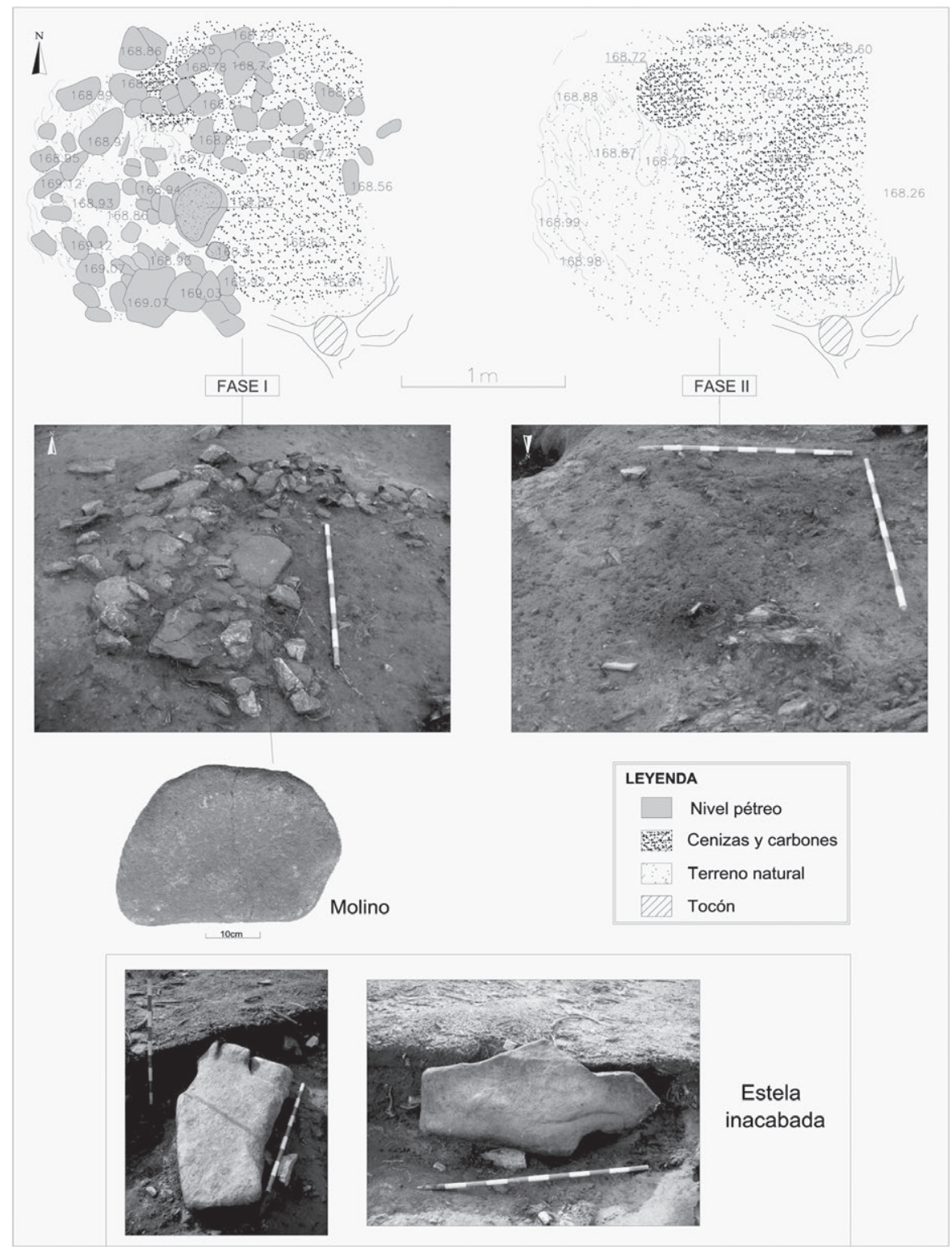

Figura 6. Estructura pétrea con molino ADA08. Fases de excavación y articulación estratigráfica $^{24}$. Fotografías de la cara ventral y dorsal de la estela inacabada ${ }^{25}$.

\footnotetext{
${ }^{24}$ A partir de Pablo VÁzquez Liz y M. Pilar Prieto Martínez, "Los yacimientos de A Devesa...", fig. 5, pág. 219.

${ }^{25}$ A partir de Pablo VÁzquez Liz, Escavación arqueolóxica do xacemento..., lámina 11.
} 

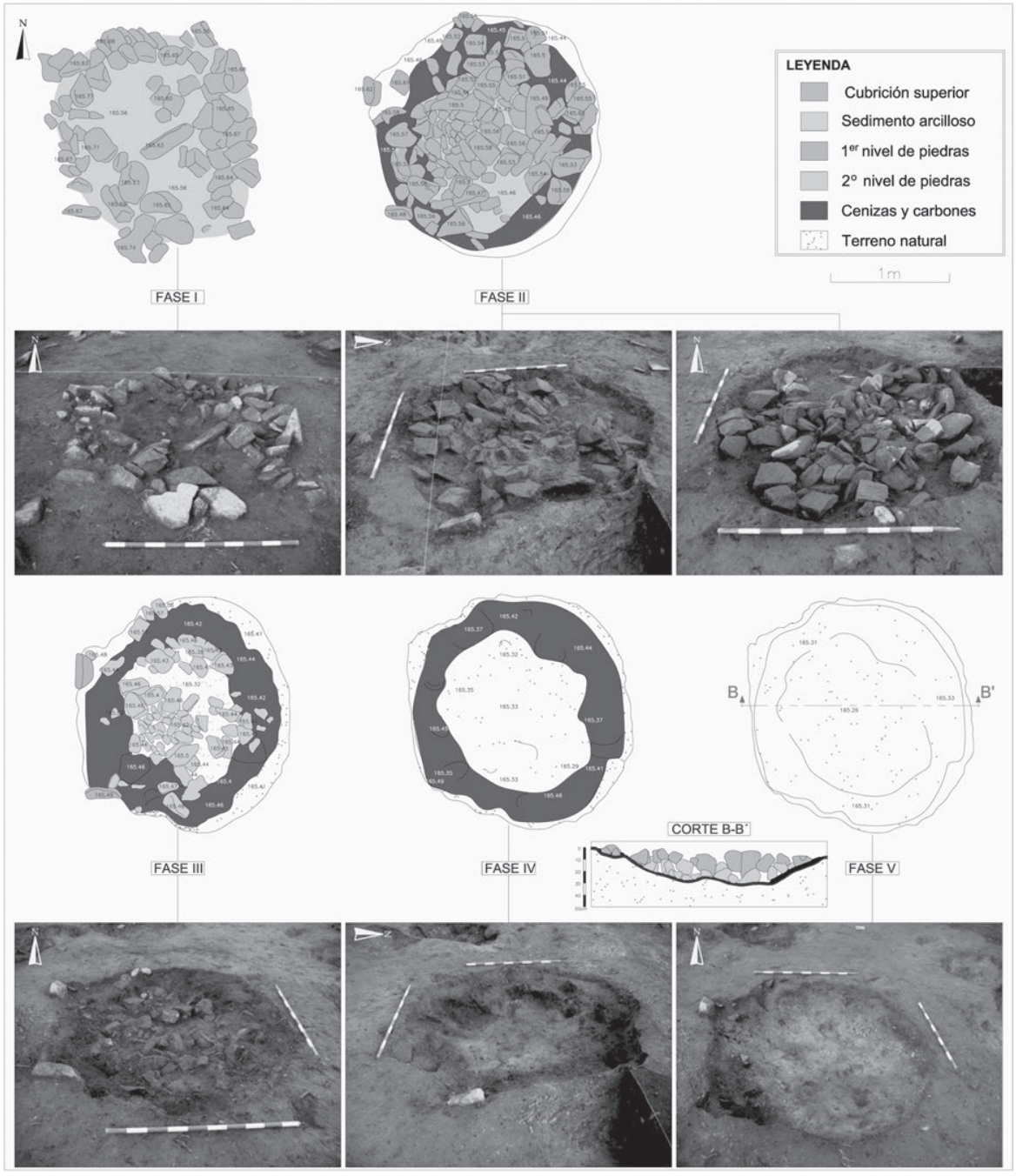

Figura 7. Estructura de enterramiento ADA06. Fases de excavación y articulación estratigráfica ${ }^{26}$.

\footnotetext{
${ }^{26}$ A partir de Pablo Vázquez Liz y M. Pilar Prieto Martínez, "Los yacimientos de A Devesa...”, fig. 5, pág. 219.
} 

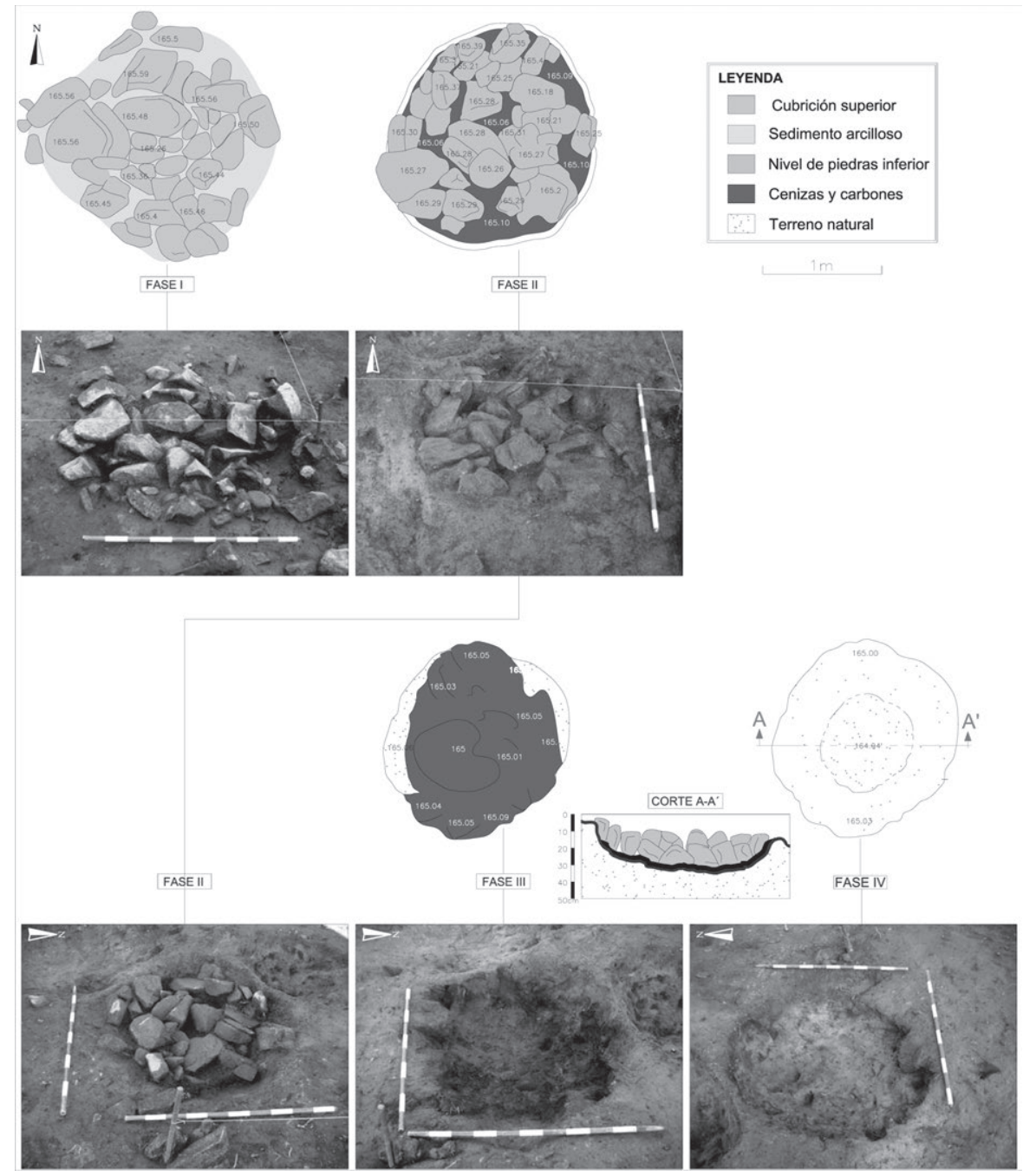

Figura 8. Estructura de enterramiento ADA07. Fases de excavación y articulación estratigráfica ${ }^{27}$.

\footnotetext{
${ }^{27}$ A partir de Pablo VÁzquez Liz y M. Pilar Prieto Martínez, "Los yacimientos de A Devesa...", fig. 5, pág. 219.
} 


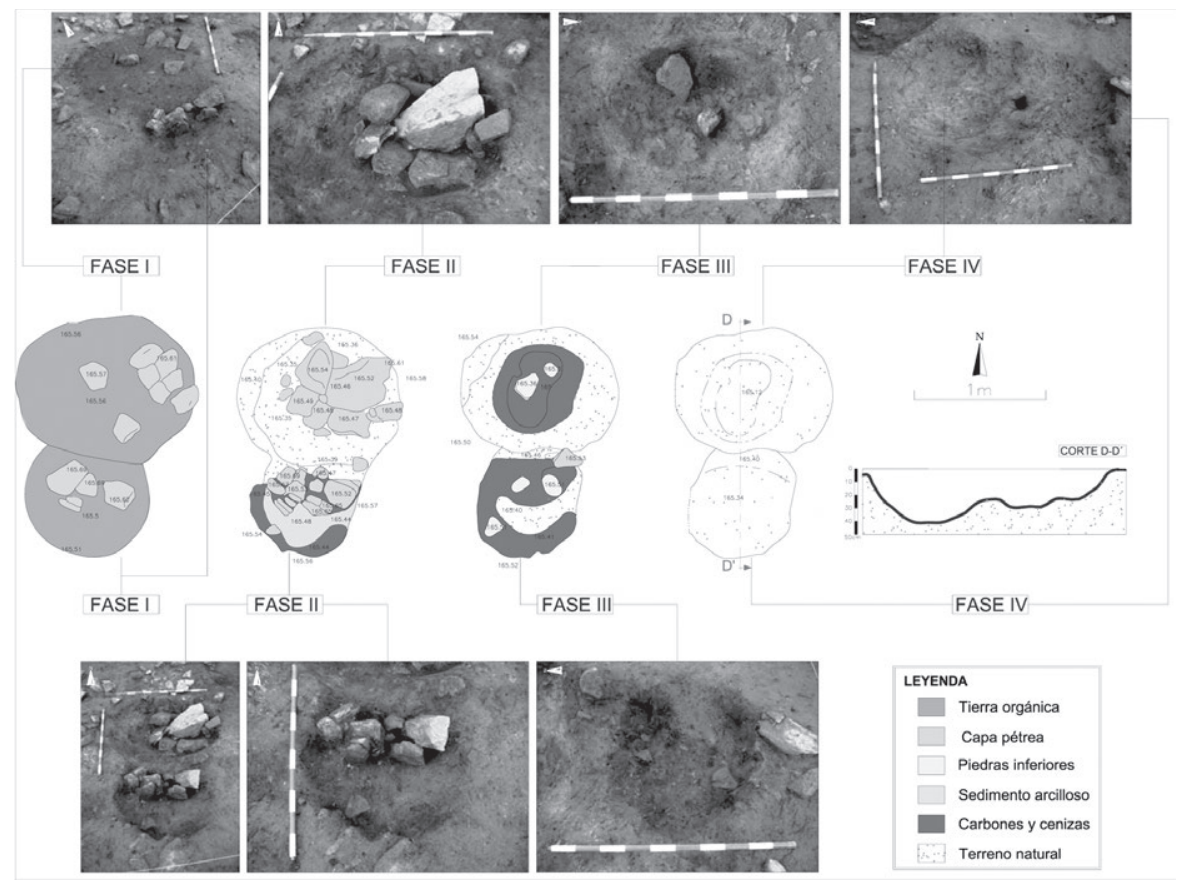

Figura 9. Fosa funeraria altomedieval ADA03 y hogar ADA04. Fases de excavación y articulación estratigráfica ${ }^{28}$.

Si nos centramos en la función de las estructuras, podemos destacar que hay al menos tres tumbas: una cista (ADA01) y dos fosas (ADA06 y ADA07). Mientras que la cista es un tipo de estructura funeraria bien conocida en la región, las fosas pueden plantear más problemas interpretativos, dada la ausencia de huesos humanos o ajuar típico de acompañamiento que lo puedan corroborar claramente, por lo tanto debemos detenernos en esta cuestión, dado que es uno de los aspectos importantes de este trabajo. Debemos destacar que la ausencia de huesos no es determinante, pues el suelo ácido gallego impide su conservación. La falta de ajuar típico tampoco debe hacernos descartar la posibilidad de interpretar estas estructuras como tumbas.

Existen paralelos de fosas funerarias coherentes cronológica y formalmente con las de ADA en otras regiones europeas (Fig. 10). Para la península Ibérica podemos destacar el yacimiento de Los Cascajos (Los Arcos, Navarra), con poblado y necrópolis de finales del $\mathrm{V}$ y comienzos del IV milenio cal. $\mathrm{BC}$, en

\footnotetext{
${ }^{28}$ A partir de Pablo Vázquez Liz y M. Pilar Prieto Martínez, "Los yacimientos de A Devesa...”, fig. 5, pág. 219.
} 
el que de un total de 37 inhumaciones individuales en fosas o cubetas, de alrededor de $1 \mathrm{~m}$ de diámetro y $0,5 \mathrm{~m}$ de profundidad, la mitad carecían de ajuar de acompañamiento ${ }^{29}$ o el yacimiento de El Tomillar (Bercial de Zapardiel, Ávila), constituido por un pequeño poblado y su cementerio, englobado dentro del área de habitación ${ }^{30}$, con 5 fosas de distinta funcionalidad, de la que destaca la Fosa $\mathrm{I}$, de 1,50 $\mathrm{m}$ de diámetro y una profundidad de entre 0,26 y $0,32 \mathrm{~m}$, datada en la segunda mitad del III milenio cal BC, donde fueron inhumados 4 individuos, así como restos sueltos de otros 7, sin ajuar, interpretada como enterramiento colectivo a modo de panteón ${ }^{31}$. Para fechas aún más tempranas se puede citar el yacimiento habitacional de La Lámpara (Ambrona, Soria) compuesto por 18 hoyos de distinta finalidad, pero en los que destacan los silos, y en particular el hoyo 1, con una inhumación individual con ajuar, datada en el 5200-5000 BC e interpretada como un silo reutilizado o como una tumba que reproduce un silo ${ }^{32}$. En el resto de Europa, sobresale la amplia franja en media luna que se extiende desde el mediodía francés al centro de Polonia, y que engloba grupos culturales como Chasséen, Munzingen, Michelsberg, etc, en los que prosperan durante el 4500-3500 BC las fosas circulares conteniendo restos humanos (esqueletos completos, partes de los mismos o restos aislados) con o sin ajuar. Como ejemplos, la Fosa 8 de la zona 2 del sitio Mulhouse-Didenheim, en el Alto Rin (Alsacia, Francia), de 1,20 m de diámetro, perteneciente al grupo cultural Munzingen, fechado entre el $4150 \mathrm{y}$ el 3580 cal. BC, donde fueron enterrados dos individuos, así como restos de otros dos, aparentemente sin ajuar ${ }^{33}$, la fosa de Grossmehring (Baviera, Alemania) de la cultura Münchshöfen (4500-3800 BC) y la de Oberderdingen-Grossvillars (Bade-Wurtemberg, SW de Alemania) de la cultura Michelsberg ${ }^{34}$.

\footnotetext{
${ }^{29}$ Alfonso Alday Ruiz, Lourdes Montes Ramírez y Vicente Baldellou Martínez, "Cuenca del Ebro", en Manuel A. Rojo Pena, Rafael Garrido Pena e Iñigo García Martínez de Lagrán (coords), El Neolítico en la Península Ibérica y su Contexto Europeo, Madrid, Ediciones Cátedra, 2012, págs. 318-319.

30 José Francisco FABIÁN GARCíA, El aspecto funerario durante el Calcolitico y los inicios de la Edad del Bronce en la Meseta Norte, Salamanca, Ediciones Universidad de Salamanca, 1995 (Estudios Históricos y Geográficos, 93), pág. 97.

31 José Francisco FABIÁN García, El aspecto funerario..., pág. 38.

32 Manuel A. Rojo Guerra, Miguel Kunst, Rafael Garrido Pena, Ínigo García Martínez-de-Lagrán, Guillermo MorÁn DAuchez, Paisajes de la memoria: asentamientos del neolítico antiguo en el valle de Ambrona (Soria, España), Valladolid, Universidad de Valladolid, 2008 (Serie Arte y Arqueología, 23), pág. 393.

${ }^{33}$ Christian Jeunesse, "Les sépultures en fosses circulaires de 1'horizon 4500-3500: contribution à 1'étude comparée des systèmes funéraires du Néolithique européen”, en Luc Baray y Bruno Boulestin (dirs.), Morts anormaux e sépultures bizarres. Les dépôts humains en fosses circulaires et en silos du Néolithique à l'âge du Fer, Dijon, Éditions Universitaires de Dijon, Collection Art, Archéologie et Patrimoine, 2010, pág. 33.

${ }^{34}$ Christian Jeunesse, "Les sépultures en fosses...".
} 


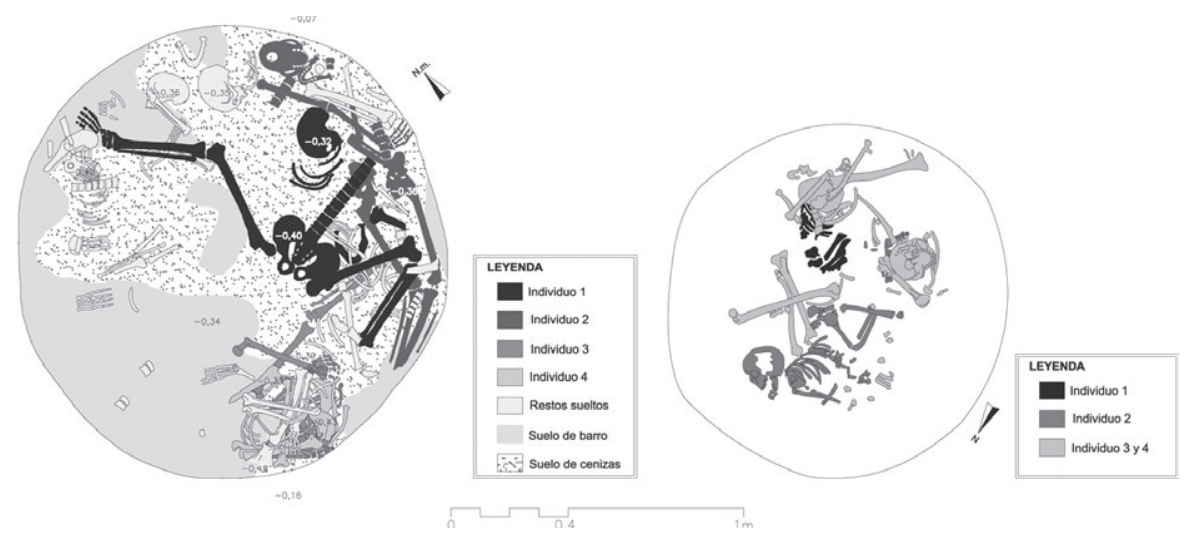

Figura 10. Ejemplos de enterramientos en fosa sin ajuar del IV y III milenios BC. A la izquierda, Fosa I del Tomillar ${ }^{35}$; a la derecha, Fosa 8, zona 2 de Mulhouse-Didenheim ${ }^{36}$.

Los criterios para considerar las fosas ADA06 y ADA07 enterramientos se fundamentan, en primer lugar, en sus dimensiones globales y su morfología que son coherentes con las que presentan las estructuras de este tipo destinadas inequívocamente esa función, al menos hasta el II milenio cal. BC, período en el que nuevas formas de apariencia más antropomorfa rompen la tendencia circular de los milenios anteriores (Tapado da Caldeira, O Pego, Quinta de Amorim...) ${ }^{37}$, aunque esta última se mantendrá también a lo largo del referido período (v.g. Fraga do Zorro, Terraço da Foz do Meal, Terraço das Laranjeiras...) ${ }^{38}$ (Fig. 11); en segundo lugar, en las características y articulación estratigráfica de las unidades

${ }_{35}$ A partir de José Francisco Fabián García, El aspecto funerario..., figs. 6, 8-12, págs. 30, 33-37.

${ }^{36}$ A partir de Christian Jeunesse, "Les sépultures en fosses...", fig. 5, pág. 33.

${ }^{37}$ Susana O. Jorge, "A Estação Arqueológica do Tapado da Caldeira (Baião)", Portugália NS, I (1980), págs. 29-50; Hugo Sampaio y Ana M.S. Bettencourt, "Between the valley and the hill top. Discoursing on the spatial importance of Pego's Bronze Age necropolis, Braga (northwest of Portugal)", Estudos do Quaternário, 10 (2014), págs. 45-57; Hugo Aluai SAmpaIo, Maria Joâo Amorim, Luciano Vilas Boas y Ana Catarina Braga, "Contributo para o estudo dos contextos funerários do noroeste português: o caso de estudo da Quinta do Amorim 2, Braga", Estudos do Quaternário, 10 (2014). págs. 35-43.

38 M. Pilar Prieto Martínez, Antonio Martínez Cortizas, Óscar Lantes Suárez y Dolores Gil Agra, "Estudio de la cerámica el yacimiento de fosas de Fraga do Zorro", Aquae Flaviae, 41 (2009), págs. 107-121; Rita Gaspar, Joana Carrondo, Luís Nobre, Zélia Rodrigues y Glòria Donoso, "Espaço para a morte. O Terraço da Foz do Medal (vale do Sabor, nordeste de Portugal) durante a Idade do Bronze”, Estudos do Quaternário, 10 (2014), págs. 59-72; Rita GaSPAR, Ricardo Ribeiro, Paulo Rebelo, Nuno Neto y Maria Luís Carvalho, "Bronze Age Funerary Context in Northeast Portugal. Terraço das Laranjeiras (Sabor Valley)", en Ana M.S. Bettencourt, Beatriz Comendador Rey, Hugo Aluai Sampaio y Edite Sá (eds.), Corpos e Metais na Fachada Atlântica de Ibéria. Do Neolítico à Idade de Bronze, Braga, APEC, CITCEM, 2014, págs. 49-62. 
que conforman las fosas de ADA que también apuntan a su función funeraria, principalmente la existencia de un lecho de carbones y cenizas de escasa potencia que se limita a cubrir la base y las paredes de la fosa, sin un desarrollo vertical o recrecimiento como ocurre en las estructuras de combustión tipo parrilla de piedra documentadas en el noroeste ibérico ${ }^{39}$, y que además, por lo menos en la fosa ADA07 no procede de una quema in situ, sino de una aportación ${ }^{40}$, así como la presencia de una potente capa de piedras que destaca por su homogeneidad material con la función de cubrir los enterramientos probablemente al término de su ciclo de uso; en tercer lugar, y quizás la razón más concluyente, es su sellado. En efecto, además de la capa de piedras reseñada, hay un sedimento arcilloso que se extiende por las estructuras y su entorno (UE1004), con la finalidad de taparlas y preservarlas. Este afán de ocultación es complementado con el revestimiento pétreo superficial que delimita la totalidad del yacimiento (UE1003), y que llega a borrar superficialmente cualquier señal de los enterramientos. La circunstancia de preservar y ocultar las estructuras parece responder al importante papel ritual que desempeñaría el lugar desde la construcción de la primera tumba y que se mantuvo al menos hasta su clausura definitiva, algo más de un milenio después, aunque el recuerdo y transmisión de sus connotaciones funerarias y rituales, materializadas en parte en la deposición de cacharros o ruptura de los mismos sobre la capa de piedra, parece que se extiende a las comunidades del II milenio, perdurando incluso hasta época altomedieval si se considera la validez de la datación de la estructura ADA03.

Aun así y desde una visión arqueológica más crítica, la ausencia de ajuar y de restos óseos pueden ser argumentos más que válidos para poner en entredicho o cuestionar el papel funerario de ambas estructuras, aparte del hecho de que un buen número de las fosas que integran los yacimientos del neolítico medio y final mejor conocidos en la península Ibérica para estos momentos no son de finalidad funeraria, pues muchas funcionan de silos o incluso de basureros. Lo que ocurre es que en la mayoría de esos casos las necrópolis o agrupaciones de tumbas están articuladas en los propios asentamientos o son contiguas a los mismos, aspecto que el registro arqueológico documentado en el lugar de ADA no verifica de ningún modo, pues el lugar de habitación más próximo con el que se puede vincular el yacimiento, por lo menos en su fase campaniforme, se

\footnotetext{
${ }^{39}$ María Martín Seijo y Paloma Uzquiano Ollero, "Análisis antracológico de estructuras de combustión neolíticas en el Noroeste peninsular: Porto dos Valos, A Gándara y Monte dos Remedios (Provincia de Pontevedra, Galicia)", en Ana M.S. Bettencourt, M. I. Caetano Alves \& Sérgio Monteiro-Rodrigues (eds.), Variações Paleoambientais e Evolução Antrópica no Quaternário do Ocidente Peninsular, Braga, APEQ-CITCEM, 2010, págs. 125-132.

${ }^{40}$ Antonio Martínez Cortizas, Manuela Costa Casais, Cruz Ferro Vázquez y Cristina Ferrín Prieto, Tratamento das mostras do xacemento arqueolóxico de Devesa de Abaixo. Santiago de Compostela: Informe Final Inédito, Laboratorio de Patrimonio, Paleoambiente e Paisaxe, USC, 2006, pág. 24.
} 
encuentra a $150 \mathrm{~m}$ al SE, sobre un rellano, y del que proceden la mayor parte de los materiales en posición secundaria recuperados en OTR. Otra cuestión sobre la que se considera importante incidir es en las propias características formales de las tumbas de ADA, pues para nada son equiparables a la mayor parte de los hoyos documentados principalmente en la Meseta, con una profundidad media muchísimo mayor y una sección muy diferente, de tipo generalmente globular, destinados principalmente a silos o basureros, lo que invalida sin lugar a dudas su posible correspondencia con ese tipo de estructuras. En este sentido, tan solo la fosa funeraria $\mathrm{n}^{\circ} 1$ del Tomillar resulta equiparable a nivel formal con la tumba ADA06. La propia articulación estratigráfica y morfológica de ADA entendidas en su globalidad muestran una serie de pautas que apuntan claramente a un contexto funerario: la elección de una forma fisiográfica totalmente individualizada con respecto al entorno circundante que sobresale a nivel visual, dos estructuras en fosa con un lecho de carbones de base colmatados con una capa de piedras y a su vez selladas con un depósito de arcilla que se amplía al entorno inmediato de las estructuras, enclavadas en la zona de menor pendiente del espolón; presencia de materiales arqueológicos en esa capa arcillosa, vinculados a la deposición ritual de vasijas o fragmentos de las mismas alrededor de las estructuras; cubrición final de la mancha arcillosa y su entorno, con un nivel de piedras proveniente del afloramiento que delimita el espolón por el E y adaptado a su forma, sobre el que se deposita una gran cantidad de material cerámico y lítico; presencia de otras estructuras de enterramiento que remarcan el contexto funerario y sagrado del sitio, como son la cista y el cofre pétreo de época altomedieval; y por último la dificultad de asignar de manera coherente otro propósito distinto al planteado para las estructuras ADA06 y ADA07, pues por su morfología, constitución estratigráfica, posición y contexto arqueológico adyacente se descarta de manera categórica su posible correspondencia con estructuras de combustión, silos, hornos o basureros, por lo que su significado funerario o en su defecto ritual parece estar fuera de toda duda, como justificaremos a lo largo del artículo.

\section{A Devesa de Abaixo: Las fechas radiocarbónicas}

La datación de varias estructuras de ADA ha proporcionado sorpresas interesantes, centrándose en 3 momentos de uso. Fueron fechadas siete muestras (Tabla 2), seis provienen de fragmentos de carbón recogidos de depósitos de combustión y una del sedimento inferior de relleno de la cista (DVS-28). Han sido medidas con la técnica de AMS (Accelerator Mass Spectrometry). Para la calibración de los resultados se ha utilizado el programa $\mathrm{OxCal}$ versión 4.2., con curva de calibración INTCAL13. Las dataciones proceden de seis estructuras y de los residuos adheridos a la pared interna de un recipiente. Los resultados han permitido concretar 


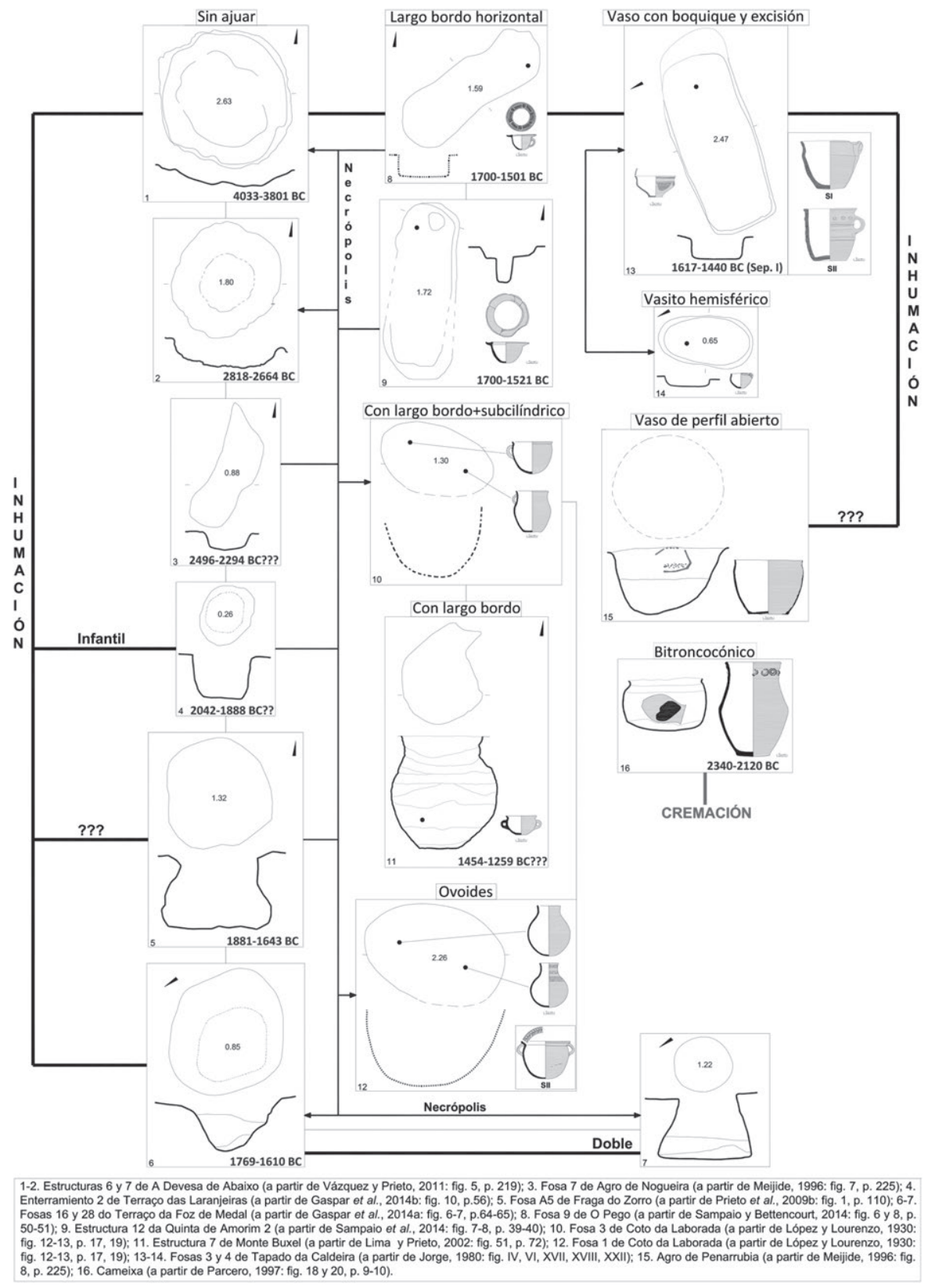

Figura 11. Síntesis gráfica de las fosas del noroeste peninsular organizada por el mobiliario de acompañamiento. 
Tabla 2. Dataciones del yacimiento de ADA

\begin{tabular}{|c|c|c|c|c|c|}
\hline MUESTRA & EDAD BP & $\begin{array}{l}\text { EDAD BC } \\
(2 \sigma)\end{array}$ & $\begin{array}{l}\text { PROBABILIDAD } \\
(95,4 \%)\end{array}$ & MATERIAL & PROCEDENCIA \\
\hline $\begin{array}{c}\text { CAADA026/ } \\
\text { Beta-354141 }\end{array}$ & $5510 \pm 30$ & $4448-4274$ & $\begin{array}{c}4406-4326 \\
(78,1 \%)\end{array}$ & \begin{tabular}{|l|} 
Residuos \\
orgánicos
\end{tabular} & $\begin{array}{l}\text { Pared interna del cacharro } 26 \text { de ADA, } \\
\text { sobre la capa de piedra de revestimiento }\end{array}$ \\
\hline $\begin{array}{l}\text { DVS-19/ } \\
\text { Ua-39918 }\end{array}$ & $5128 \pm 34$ & $4033-3801$ & $\begin{array}{c}3992-3907 \\
(52,6 \%) \\
3880-3801 \\
(41,9 \%)\end{array}$ & Carbón & $\begin{array}{l}\text { Nivel inferior de relleno de una gran fosa } \\
\text { abierta en el substrato }\end{array}$ \\
\hline $\begin{array}{c}\text { DVS-20/ } \\
\text { Beta-278856 }\end{array}$ & $4200 \pm 40$ & $2900-2638$ & $\begin{array}{c}2818-2664 \\
(67,1 \%)\end{array}$ & Carbón & $\begin{array}{l}\text { Nivel inferior de relleno de una fosa } \\
\text { abierta en el substrato. }\end{array}$ \\
\hline $\begin{array}{c}\text { DVS-28 } \\
\text { Beta-365865 }\end{array}$ & $4100 \pm 30$ & $2862-2570$ & $\begin{array}{c}2707-2570 \\
(62,3 \%)\end{array}$ & Sedimento & Depósito inferior de relleno de una cista \\
\hline $\begin{array}{c}\text { DVS- } 18 / \\
\text { Beta-354145 }\end{array}$ & $4100 \pm 30$ & $2862-2570$ & $\begin{array}{c}2707-2570 \\
(62,3 \%)\end{array}$ & $\begin{array}{c}\text { Carbón de } \\
\text { quercus }\end{array}$ & $\begin{array}{l}\text { Depósito orgánico sellado por una } \\
\text { estructura de piedra }\end{array}$ \\
\hline $\begin{array}{l}\text { DVS-16/ } \\
\text { Ua-39917 }\end{array}$ & $4057 \pm 37$ & $2850-2475$ & $\begin{array}{c}2680-2475 \\
(84,7 \%)\end{array}$ & Carbón & Nivel de carbonización de un hogar \\
\hline $\begin{array}{l}\text { DVS-15/ } \\
\text { Ua-39916 }\end{array}$ & $1234 \pm 30$ & 687-880 AD & $\begin{array}{l}687-880 \\
(95,4 \%)\end{array}$ & Carbón & $\begin{array}{l}\text { Nivel de carbonización en la base de una } \\
\text { pequeña estructura lítica en fosa }\end{array}$ \\
\hline
\end{tabular}

la cronología del yacimiento y algunos de los estilos cerámicos documentados, en muchos casos sin paralelos en la región. A continuación, se indican de forma somera los rasgos más significativos de cada una de las muestras, así como una valoración de las mismas, ordenadas de la más antigua a la más reciente.

En un primer momento de uso adscribible al Neolítico Medio de la región, disponemos de dos muestras datadas:

- CAADA026 (Fig. 12): muestra procedente de la pared interna de un fragmento de panza perteneciente a un cacharro de forma desconocida, con decoración incisa fina. Ésta fue recuperada en el relleno interior de un rebaje provocado por la explotación forestal, en los límites suroccidentales de la capa de piedra que reviste el yacimiento. De acuerdo al resultado de la datación, el vaso cerámico sería usado en la segunda mitad del IV milenio en el intervalo 4406-4327 BC. Se trata de la primera evidencia de ocupación humana de la zona en la que se enclava el yacimiento, quizás de tipo testimonial, pues están ausentes las estructuras de esta época. 


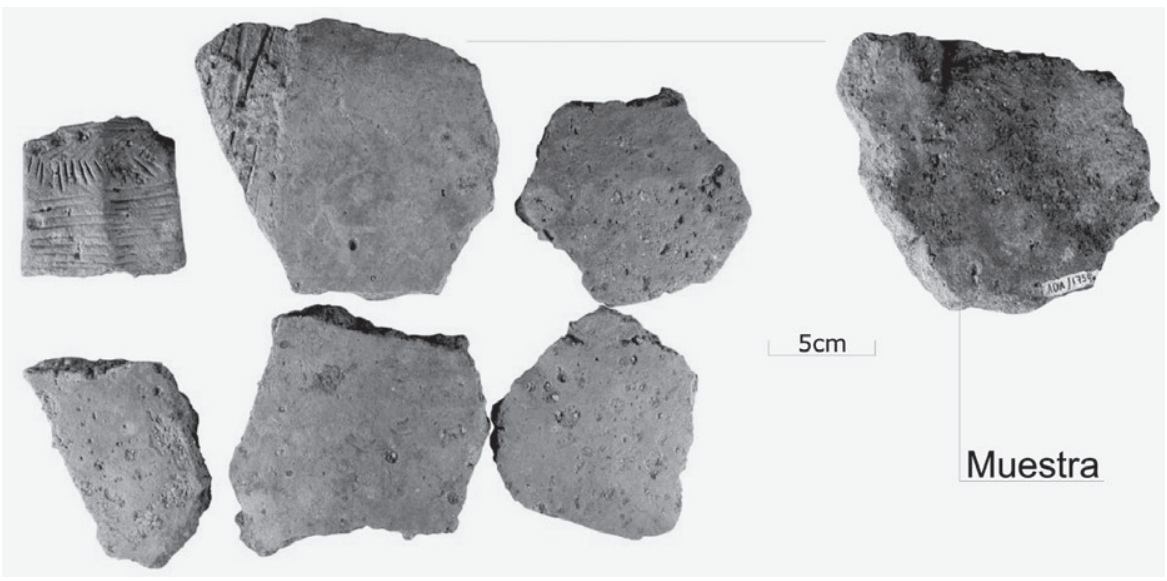

Figura 12. Fotografías de los fragmentos que integran la vasija CAADA026, indicando la pieza de procedencia de la muestra datada.

- La segunda muestra fue extraída del depósito de carbones y cenizas de planta anular (DVS-19) dispuesto sobre el fondo y la pared de la fosa de enterramiento ADA06. Se constata el uso de la estructura entre el 4033-3801 BC. Sin embargo, cabe la posibilidad de que estén presentes carbones de distintas épocas en la muestra analizada, pues estudios todavía inéditos ${ }^{41}$ demuestran que la combustión no está in situ y que el material es una aportación de otro lugar por lo que una vez efectuada la combustión se pudieron agregar carbones más antiguos durante la recogida del sedimento para su posterior incorporación a la fosa. En el caso de aceptar su datación como correcta podemos afirmar que se trata del enterramiento en fosa más antiguo del noroeste ibérico. Un problema imposible de solucionar es el tipo de enterramiento que acogería el hoyo y el período que estuvo vigente. La ausencia de restos humanos y mobiliario no permite aproximarnos a la realidad arqueológica original. Aunque semeja que la estructura acogería como rito de enterramiento la inhumación, desconocemos si hubo tratamiento previo del cuerpo, o si fue un enterramiento colectivo simultáneo o no simultáneo, o individual múltiple. Por las medidas de la fosa y por paralelos con estructuras semejantes a nivel formal, el enterramiento colectivo con la incorporación de cuerpos descarnados o en el límite de su desconexión anatómica, dada la moderada profundidad del rebaje de la fosa, es el que parece cobrar más fuerza. En cuanto al periodo de vigencia

\footnotetext{
${ }_{41}$ Antonio Martínez Cortizas, Manuela Costa Casais, Cruz Ferro Vázquez y Cristina Ferrín Prieto, Tratamento das mostras de... pág. 24.
} 
del enterramiento, si aceptamos la información proporcionada por las dataciones que veremos seguidamente, existe un intervalo de algo de más 1.000 años, entre esta estructura y la siguiente. A pesar de la ausencia de ajuar, la presencia de fragmentos de cacharros del Neolítico Medio y Final en el entorno contiguo de la estructura, muestran inequívocamente la deposición de cerámica, bien con las formas completas o bien con fragmentos, continuando la tradición anterior, pero en este caso ya vinculada a un elemento claramente humano, que le otorga a la estructura unas importantes connotaciones simbólicas que trascienden su función original de tumba, a la de lugar de reposo de los antepasados en un primer momento y de los ancestros con posterioridad, ampliando esas connotaciones a la totalidad del espolón.

En un segundo momento, que se corresponde con la primera mitad del III milenio BC, la fase final del Neolítico (o Calcolítico Inicial y Pleno en terminología de la región), disponemos de 4 dataciones:

- Una muestra extraída del depósito de carbones y cenizas (DVS-20) que cubre la fosa de enterramiento ADA07, interpretado como lecho de deposición de los restos humanos que pudo contener la estructura, verifica su utilización en el 2818-2664 BC, más de 1000 años más reciente que la estructura ADA06. A pesar de sus semejanzas con ADA06, presenta sus propias peculiaridades, su dimensión en planta es menor, la disposición del depósito de combustión recubre la totalidad del fondo y las paredes de la estructura y las piedras de cubrición son menos abundantes pero de tamaño más homogéneo. Estas diferencias pueden responder a una distinta cronología de las estructuras. Para las cuestiones relativas al tipo de enterramiento que pudo acoger, así como a su período de vigencia nos remitimos a lo expuesto en ADA06, pues como sucede en esta, carecemos de restos humanos y de ajuar de acompañamiento que pudieran arrojar luz sobre los aspectos mencionados. Aun así, en lo relativo al tiempo de vigencia y gracias a la disponibilidad de una fecha proveniente de la estructura de combustión ADA04, acondicionada con posterioridad a la cubrición o sellado con el sedimento arcilloso de las tumbas y entorno y datada entre el 2680-2475 BC, se puede suponer que el uso de la estructura se limitó a algo más de 100 años.

- Una muestra de carbón proveniente del depósito inferior de relleno (DVS28) de la estructura funeraria ADA01 o cista. Ésta era problemática pues procede del sedimento natural removido por la violación de la estructura. Así, y aunque la fecha es coherente con otras del III milenio procedentes del yacimiento, 2707-2570 BC, no tenemos certeza de que se esté datando su momento de uso. La fecha más antigua para las cistas de la región es 
de 2565-2294 BC (cista de cremación de Agro de Nogueira ${ }^{42}$, Toques, A Coruña y las propias características formales de la estructura nos remiten más bien a formas del II milenio BC (Praia da Rola o Gandón 2) (Fig. 13). Por lo tanto, o pensamos en una posible contaminación para la muestra de ADA01 o si la aceptamos como correcta dada su coherencia con las fechas de otras estructuras, nos encontramos ante la cista más antigua de la región.

- Una muestra procedente de un nivel de carbones y cenizas (DVS-18) sellado por una capa de piedras con un durmiente de molino completo en su centro o ADA08. Se trata de la estructura más alejada del área funeraria conformada por las tumbas neolíticas y otras estructuras asociadas, cuya finalidad resulta imprecisa, pues el depósito orgánico descansa directamente sobre el terreno natural, lo que en principio descarta su uso funerario, y al igual que la estructura ADA06 este depósito no pertenece a una quema in $s_{i t u}{ }^{43}$, por lo que debemos excluirla como una estructura de combustión. La fecha obtenida, 2707-2570 BC, similar a la proporcionada por la cista ADA01, pone de manifiesto la intensa actividad humana registrada en el yacimiento en la primera mitad del III milenio.

- Una muestra de un nivel de carbones y cenizas (DVS-16) de la estructura de combustión ADA04, acondicionada en el sector central del área funeraria, definida ésta por la mancha o depósito arcilloso que cubre las tumbas neolíticas y entorno inmediato. Esta estructura fue acondicionada con posterioridad a la ocultación del área funeraria por el nivel de arcilla, ya que rompe a éste. La datación confirma el uso de la estructura entre el 2680-2475BC, quizás relacionada con la reutilización campaniforme del lugar.

Finalmente, la última fase datada se corresponde con un momento de uso en época altomedieval:

- La muestra analizada (DVS-15) procede de un pequeño y fino depósito de carbonización situado en el fondo de la fosa ADA03, cubierto por una agrupación de piedras que esbozan una forma en caja. Esta estructura se superpone parcialmente sobre la ADA04 y esta relación estratigráfica hizo plantear la proximidad cronológica de ambas. Los resultados radiocarbónicos rebaten esta hipótesis, pues nos remite a época histórica, 687-880 AD. Aunque es mucho más tardía que las restantes fechas del

\footnotetext{
${ }_{42}$ Gonzalo MeiJide Cameselle, "La necrópolis del Bronce Inicial del Agro de Nogueira (Piñeiro, Toques, A Coruña) en el contexto funerario de su época" en Humanitas. Estudios en Homenaxe ó Prof. Dr. Carlos Alonso del Real, Vol. 1, Santiago de Compostela, Universidade de Santiago de Compostela, 1996, págs. 215-239.

${ }^{43}$ Antonio Martínez Cortizas, Manuela Costa Casais, Cruz Ferro Vázquez y Cristina Ferrín Prieto, Tratamento das mostras do... pág. 24.
} 


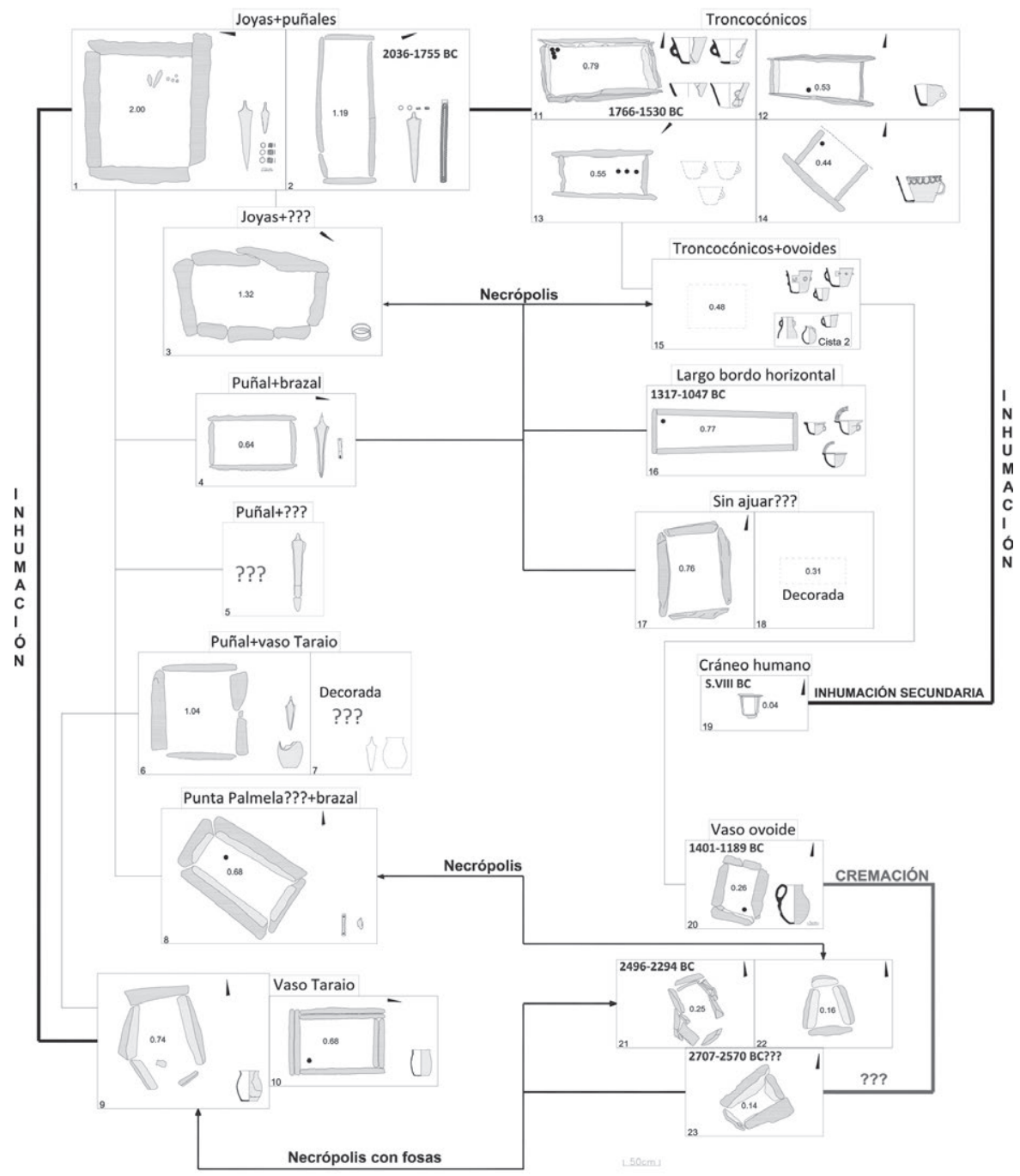

1. Atios (a partir de Vázquez, 1980a: 30); 2. Quinta de Agua Branca (a partir de Fortes, 1906; Brandherm, 2007: fig. 2, p. 74); 3. A Pedrosa 4 (a partir de Delibes y Rodriguez,1976: fig.1-2, p. 185); 4. Pedramarrada (a partir de Vázquez, 1980a: 28-29); 5. Fariñas (a partir de Vázquez, 1980a: 27); 6. Taraio (a partir de Vázquez, 1980a: 25-26.); 7. As Antas (a partir de Monteagudo et al., 1981: fig. 20, p. 158); 8. Gandón 1 (a partir de Peña, 1985: fig. 4 y 7. p. 90 y 93); 9 . Agro de Nogueira 2 (a partir de Meijide,1996: fig. 4-5, pp. 222-223); 10. O Cubilon (a partir de Ramil y Vazquez, 1979: fig. 2-3, p. 65-66.); 11. A Forxa (a partir de Prieto et al., 2009 a: fig.1, p. 94 ); 12. Lordelo (Silva y Marques, 1984: fig. II-III, p. 62-63); 13. Gorgolão 1 (a partir de Baptista, 1999); 14. Gorgoláo 2 (a partir de Silva, 1994: fig. 2-3, p. 140 y 142)15. A Pedrosa 1 (a partir de Rodriguez, 1971: 53; Suárez, 1986: fig. 36-38, p. 187,189,191); 16. Agra de Antas (a partir de Cruz y Gonçalves, 1998-1999); 17. Bicos de Lagos 2 (a partir de

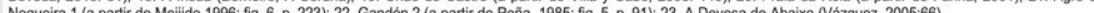

Figura 13. Síntesis gráfica de las cistas del noroeste peninsular organizada por el mobiliario de acompañamiento. 
yacimiento, debemos asumirla como correcta, ya que no se ha detectado ninguna anomalía estratigráfica. Además, es frecuente documentar restos de actividad de época medieval durante las excavaciones de túmulos prehistóricos, aunque su publicación detallada es excepcional, como es el caso de los materiales cerámicos altomedievales la Medorra 3 de Roza das Aveas (Outeiro de Rei, Lugo) ${ }^{44}$. Así que se observa un uso semejante al de las tumbas megalíticas en contextos no megalíticos de la región. Tal hecho puede estar en relación con el alto grado de atracción que siguieron ejerciendo aquellos yacimientos funerarios de una larga diacronía o de gran monumentalidad, caso de algunos túmulos o sitios sobre elementos naturales señeros como ADA, en las primeras comunidades medievales, hasta el asentamiento definitivo del cristianismo, gracias a una tradición transmitida y perpetuada de generación en generación.

\section{ADA y la cerámica: Características, distribución y problemáticas cronológicas}

La cerámica nos permite identificar y caracterizar en el yacimiento la existencia de fases que no pudieron datarse. Sin embargo, se plantea un hándicap importante para el yacimiento, el material está muy fragmentado, apenas pueden reconstruirse recipientes, cuyos fragmentos son escasos y rodados, a lo que se suma la documentación de diseños decorativos inéditos hasta el momento en el área del Morrazo y sin paralelos en la región o en zonas más lejanas, por lo cual hay que deducir las características de los mismos y vincularlos con patrones estilísticos. Esta estrategia, al igual que la tipología, es un apoyo orientativo al conocimiento de la ocupación del lugar. A partir de las dataciones se intentará asignar los recipientes neolíticos a una fase media o final, matizando un poco más el trabajo preliminar publicado sobre el yacimiento ${ }^{45}$.

Son 17 los recipientes asociados a las fases neolíticas del yacimiento. Éstos podrían estar relacionados con los tres momentos de actividad datados, dos de ellos en el neolítico medio y otro en el neolítico final. Dado que todos los recipientes presentan una cierta homogeneidad en las pastas y formas, sean de la fase media o final ${ }^{46}$, podemos tratarlos en conjunto. Se pueden clasificar en dos grupos

\footnotetext{
${ }^{44}$ M. Pilar Prieto Martínez, Óscar Lantes SuÁrez, Pablo VÁzquez Liz, y Antonio Martínez Cortizas, "La cerámica de dos túmulos de Roza das Aveas (Outeiro de Rei, Lugo): un estudio diacrónico del estilo y la composición”, BSAA arqueología, LXXVI (2010), págs. 27-62.

45 Pablo VÁzquez Liz y M. Pilar Prieto Martínez, "Los yacimientos de A Devesa...”.

${ }^{46}$ M. Pilar Prieto Martínez, "From Galicia to the Iberian Peninsula: Neolithic ceramics and traditions", en Georgiu Dragos (ed.), Early farmers, Late Foragers and Ceramic traditions. On the beginning of pottery in Europe, Cambridge, Cambridge Scholars Press, 2009, págs. 116-149.
} 
estilísticos: por un lado, la cerámica lisa, cuyos recipientes poseen morfologías simples cerradas tipo cuenco, y excepcionalmente, compuestas cerradas tipo vaso (Figs. 14-15). Un segundo grupo más complejo es el de la cerámica decorada, que presenta rasgos morfotécnicos semejantes a la cerámica lisa. Dentro de este grupo se documentan dos variantes diferenciadas por el tipo de decoración:

- Cerámica con decoración incisa y acanalada con motivos curvilíneos, en algún caso se combina la técnica de incisión con la impresión. Son diseños que se documentan en sepulturas megalíticas del neolítico medio. La cerámica decorada es escasa en la región para esta época y no hay recipientes semejantes por el momento para comparar.

- Cerámica con decoración acanalada con motivos rectilíneos, entre los que destaca el zig-zag, las líneas horizontales y oblicuas y los reticulados. Estos diseños recuerdan los esquemas decorativos de la cerámica inciso-metopada de la primera mitad del III milenio BC, si bien en este caso, el pequeño tamaño de los fragmentos no permite reconstruir con suficiente fiabilidad los diseños, como para verificar esta hipótesis.

En Galicia, la decoración en ambas fases suele ser más compleja en contextos funerarios que en asentamientos ${ }^{47}$. En particular en ADA podemos hablar de decoraciones complejas, por lo tanto, acordes con contextos no-domésticos. Así, la cerámica del neolítico medio está conformada por 11 recipientes, 8 lisos $(11,4$, $6,10,18,5,9,12)$ y 3 decorados $(26,22,7)$, un número elevado si consideramos que sólo hay una única estructura vinculada con esta fase. Estilísticamente no se pueden diferenciar las cerámicas más antiguas del V milenio de las que podrían estar asocias a la datación de la estructura de inicios del IV milenio BC. La mayor parte de las cerámicas se concentran próximas a la estructura datada. Asimismo, la cerámica del neolítico final, tiene 6 recipientes decorados asignados $(54,50,57$, $59,45,49)$. A pesar de ser la fase del yacimiento que más estructuras asociadas tiene, en cambio la cerámica no es la más abundante en número y se encuentra muy dispersa e incluso alejada de las estructuras datadas en la primera mitad del III milenio BC, su distribución es coincidente, como veremos, con la cerámica de la fase campaniforme.

El conjunto cerámico campaniforme en ADA se compone de 51 recipientes. Podemos clasificar tres grupos cerámicos o categorías ${ }^{48}: 35$ vasijas lisas $(9$ de ellas poseen cordones perimetrales en el cuello-borde), 7 vasos con decoración campaniforme y 8 vasijas con decoración no campaniforme.

\footnotetext{
${ }_{47}^{4}$ M. Pilar Prieto Martínez, "From Galicia....".

${ }^{48}$ Ver conceptos en: M. Pilar Prieto Martínez, "Bell beakers communities in Thy. The first Bronze Age society in Denmark", Norwegian Archaeological Review, 41(2) (2008), págs. 115-158; M. Pilar Prieto Martínez, "From Galicia...”.
} 
La cerámica lisa, la más abundante, presenta un predominio de morfologías simples y perfiles cerrados, siendo mayoritarios los cuencos, sin embargo, se pueden encontrar un número significativo de morfologías compuestas cerradas, tipo cazuelas carenadas, si bien se desconoce la forma de un porcentaje elevado de recipientes. En relación con las pastas podemos destacar le existencia de un grupo mayoritario de recipientes con acabados alisados toscos y otro, de acabados alisados medios. Dentro de esta categoría hay un grupo de recipientes que además posee cordones horizontales aplicados en su parte superior hacia el borde, presentando los mismos rasgos morfotécnicos que el resto de la cerámica lisa. Estos recipientes, cuyas características coinciden con las cerámicas de sitios domésticos de la región, han sido localizados en la capa lítica de revestimiento de ADA, alrededor del área funeraria, y son el resultado de una deposición posterior a las estructuras datadas y selladas por la capa de arcilla.

La cerámica campaniforme es documentada en un porcentaje elevado, 13,7\% en ADA, ya que la proporción habitual encontrada en asentamientos al aire libre gallegos ronda el 3,5\% ${ }^{49}$. Son vasos, de morfologías compuestas, aunque debido a su elevado grado de fragmentación es difícil determinar si éstas son de perfiles cerrados o abiertos. Las cerámicas de esta categoría presentan texturas compactas finas y los desgrasantes son inapreciables tanto en superficie como en fractura. Se han podido clasificar dos variantes: una primera constituida por aquellos recipientes que presentan una decoración simple incisa exclusivamente y pastas de buena calidad, y una segunda variante de recipientes con decoración compleja en la que la técnica predominante es la incisión y la combinación de incisión e impresión. La impresión como única técnica casi no está documentada en ADA, siendo el punzón el instrumento utilizado de manera exclusiva. Los motivos destacados son los reticulados y zigzags, además de las líneas rectas horizontales y oblicuas. Esta variante, también denominada campaniforme acanalado es también una variante regional tardía ${ }^{50}$, está presente únicamente en ADA, y son pocos los yacimientos en Galicia que presentan sus características, como es el caso de A Pita, Cargadoiro, As Cavadas ${ }^{51}$ y el PA45.03 de A Lagoa ${ }^{52}$. Esta cerámica presenta una distribución periférica con respecto al área funeraria, bordeándola y ocupando un espacio ajeno a la realidad neolítica como es el S. Las características de esta cerámica campaniforme difieren de la encontrada en OTR como veremos más adelante.

\footnotetext{
${ }^{49}$ M. Pilar Prieto Martínez, La Cultura Material Cerámica en la Prehistoria Reciente de Galicia: Yacimientos al Aire Libre, Santiago de Compostela, GIArPa, 2001 (TAPA, 20), pág. 20.

${ }^{50}$ M. Pilar Prieto Martínez, "La alfarería de las comunidades campaniformes en Galicia: contextos, cronologías y estilo”, en María Pilar Prieto Martínez y Laure Salanova (coords.), Las Comunidades Campaniformes en Galicia. Cambios sociales en el III y II milenios BC en el NW de la Península Ibérica, Pontevedra, Diputación de Pontevedra, 2011, págs. 333-343.

${ }^{51}$ M. Pilar Prieto Martínez, La Cultura Material... .

${ }^{52}$ M. Pilar Prieto Martínez, "El área arqueológica de A Lagoa...”. .
} 
EL YACIMIENTO DE A DEVESAS DE ABAIXO (PONTEVEDRA): MUERTE Y TRADICIÓN EN LA PREHISTORIA RECIENTE DEL NOROESTE DE LA PENÍNSULA IBÉRICA

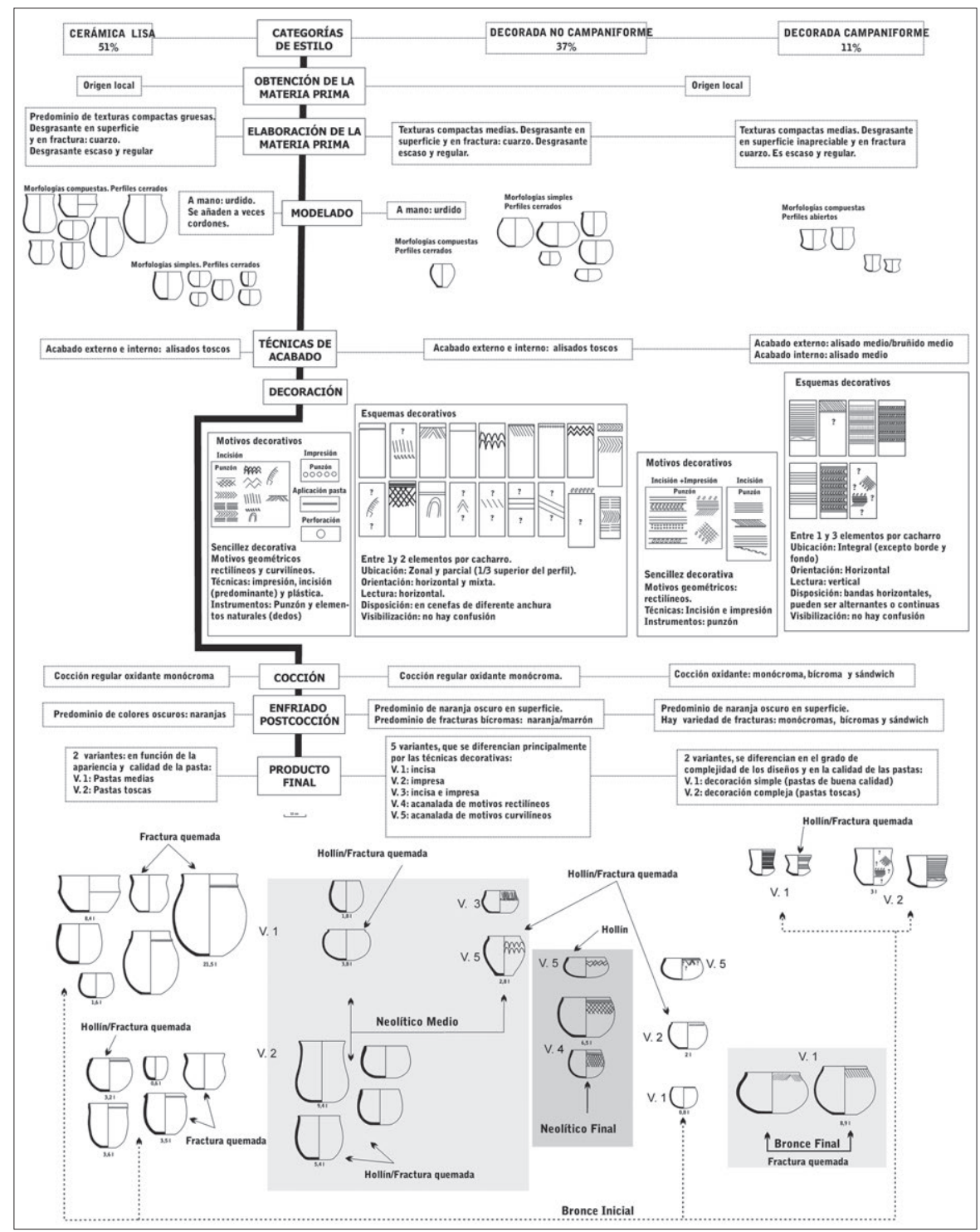

Figura 14. Esquema de la cadena operativa de ADA. Se señalan las cronologías de las distintas variantes. 


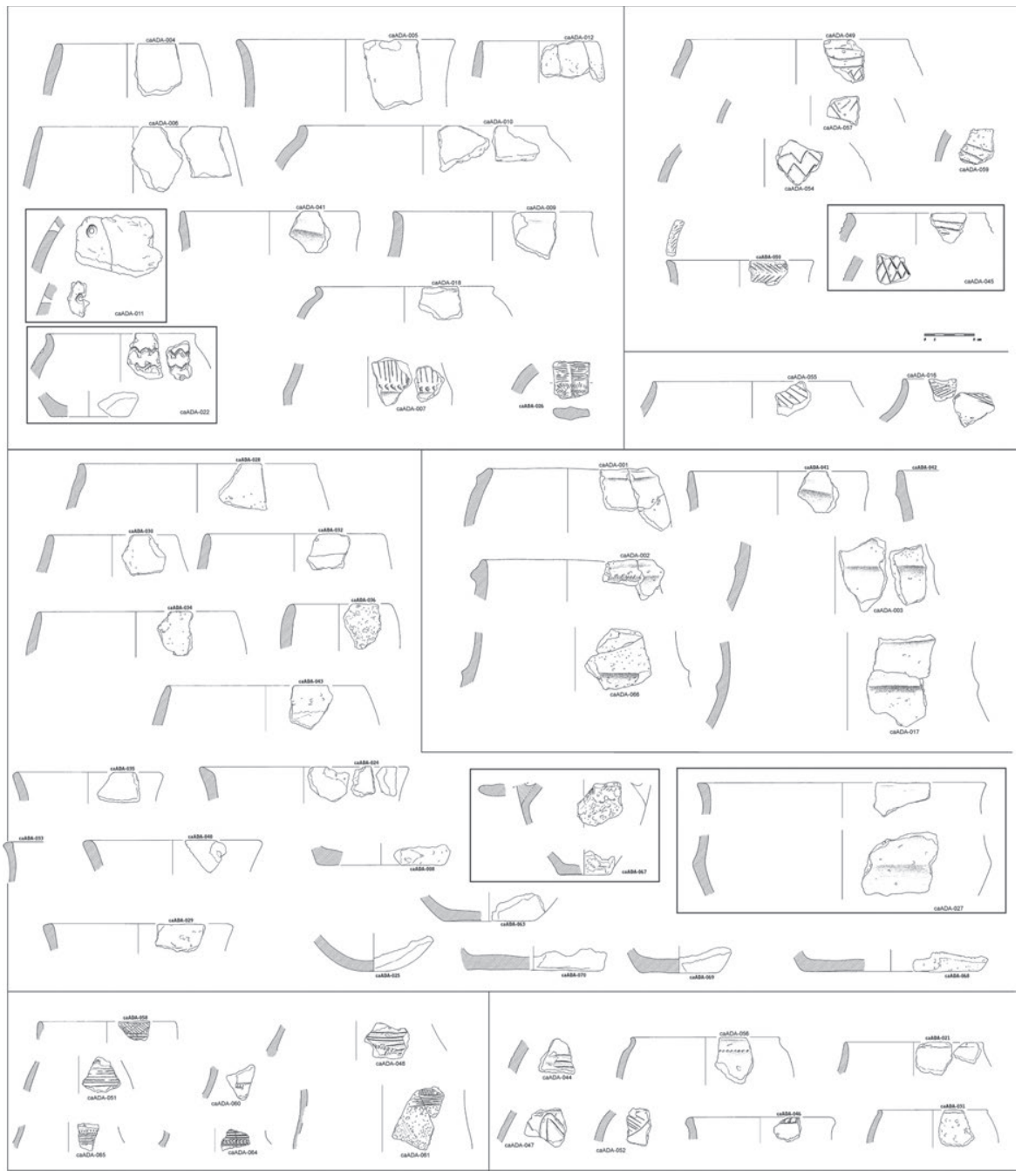

Figura 15. Dibujos de las piezas significativas de ADA (realizados por Anxo Rodríguez Paz). 
Por el contrario, la técnica de impresión realizada con instrumento dentado es la más frecuente de la región y se viene documentando en Galicia desde mediados del III milenio $\mathrm{BC}^{53}$.

La cerámica decorada no-campaniforme es el 17,6\% del conjunto, porcentaje elevado en relación con lo que se conoce para los asentamientos al aire libre gallegos. Es el único caso conocido en el que su número supera al campaniforme decorado. Se observa una variante: son recipientes de morfologías simples cerradas, pastas más toscas y una decoración impresa muy sencilla, de una o dos líneas en el borde del recipiente, constatándose asimismo en OTR. Este tipo de cerámica es todavía poco frecuente en Galicia, pero empezamos a tener constancia de su existencia en otros yacimientos gallegos como A Lagoa, Gándaras de Budiño y A Devesa do $\mathrm{Rei}^{54}$. Se distribuyen siguiendo el patrón de los fragmentos campaniformes, localizados en la periferia de las estructuras (Fig. 16).

La complejidad formal del conjunto de variantes cerámicas de la fase campaniforme permite plantear diversas hipótesis acerca de la cronología del yacimiento, que sumaremos, más adelante, al apartado de síntesis del yacimiento.

Apenas se ha documentado material asociado a una posible actividad en el Bronce Final (segunda mitad del II milenio BC), únicamente dos recipientes $\left(n^{0} 16\right.$ y 55) que poseen perfiles simples cerrados con una decoración incisa muy superficial en la que se desarrollan motivos muy sencillos, dispuestos en cenefa ancha en el tercio superior del recipiente y realizados a base de líneas oblicuas (figura 7.C). El estilo de esta cerámica coincide con la del túmulo de Devesa do $\mathrm{Rei}^{55}$, encuadrada en el último tercio del II milenio BC (Ua20012: 2990 \pm 45 BP: 1380-1051 cal BC-2 $\sigma$ ). Este material se documenta principalmente en la periferia del área funeraria, alrededor de sus límites septentrionales. No debemos descartar que puedan ser casi contemporáneas de las comunidades que depositaron en ADA los campaniformes acanalados.

\section{Os Torradoiros}

Este sector apenas presentaba estructuras en posición primaria, a excepción de una estrecha zanja de indudable adscripción prehistórica pero finalidad desco-

\footnotetext{
${ }^{53}$ M. Pilar Prieto Martínez, "La alfarería de las comunidades...”; M. Pilar Prieto Martínez, "Unity and circulation: what underlies the homogeneity of Galicia bell beaker ceramic style?" en M. Pilar Prieto Martínez y Laure Salanova (cords.), Current researches on Bell Beakers. Proceedings of the $15^{\text {th }}$ International Bell Beakers Conference: From Atlantic to Ural, Santiago de Compostela, Copynino-Centro de Impresión Digital, 2013, págs. 209-249.

${ }^{54}$ M. Pilar Prieto Martínez, "La alfarería de las comunidades...”; M. Pilar Prieto Martínez, "Unity and circulation:...".

${ }^{55}$ Marta Tabarés Domínguez y M. Pilar Prieto Martínez, "Ceramic study of the Devesa...”.
} 


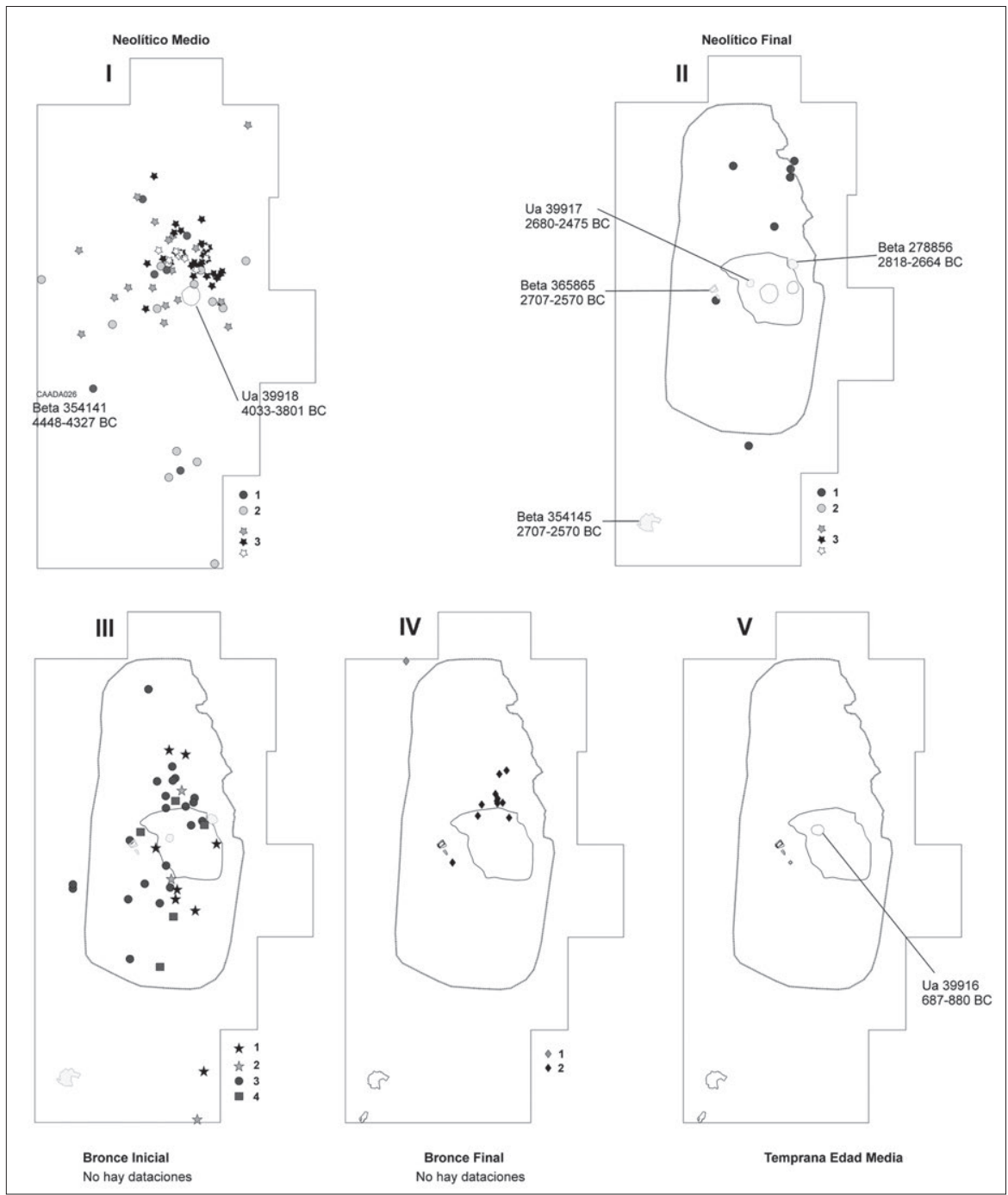

Figura 16. Distribución de las piezas en ADA según las fases del yacimiento. 
nocida, de un pequeño tramo de una zanja de cimentación de una parcelación de piedra moderna, y sobre todo una acumulación de piedras (Fig. 2) con una elevada concentración de fragmentos cerámicos (más de 600) pertenecientes al menos a 5 cacharros con decoración plástica (cordones), de difícil interpretación. No se documentaron más estructuras. La mayor parte de las piezas, destacando cerámicas campaniformes, fueron documentadas en un depósito coluvial discontinuo conformado por piedras generalmente de pequeño tamaño, proveniente de cotas superiores, donde fueron identificados en superficie materiales de características semejantes a los extraídos en excavación. Por su emplazamiento en un rellano a media ladera, podría pensarse que se enclavaría un yacimiento doméstico de una sola ocupación.

Dada la imposibilidad de datar muestras procedentes de depósitos arqueológicos, y gracias a la existencia de residuos carbonizados en el interior de las paredes del fondo de un recipiente, CAOTR027 (Fig. 17, Tabla 3), se pudo obtener una datación del uso de ese recipiente, 2139-1956 BC, coherente con el conjunto de material cerámico recuperado y con un grupo numeroso de yacimientos con cerámicas campaniformes en la región ${ }^{56}$.

Tabla 3. Datación del yacimiento de OTR

\begin{tabular}{|c|c|c|c|c|l|}
\hline MUESTRA & EDAD BP & $\begin{array}{c}\text { EDAD BC } \\
(2 \sigma)\end{array}$ & $\begin{array}{c}\text { PROBABILIDAD } \\
(95,4 \%)\end{array}$ & MATERIAL & PROCEDENCIA \\
\hline CA0TR027/ & $3670 \pm 30$ & $2139-1956$ & $\begin{array}{c}2139-1956 \\
(9504 \%)\end{array}$ & $\begin{array}{c}\text { Carbón } \\
\text { orgánicos }\end{array}$ & $\begin{array}{l}\text { Pared interna del cacharro 27 de 0TR, } \\
\text { en un depósito coluvial }\end{array}$ \\
\hline Beta-354143 & & & . & \\
\hline
\end{tabular}

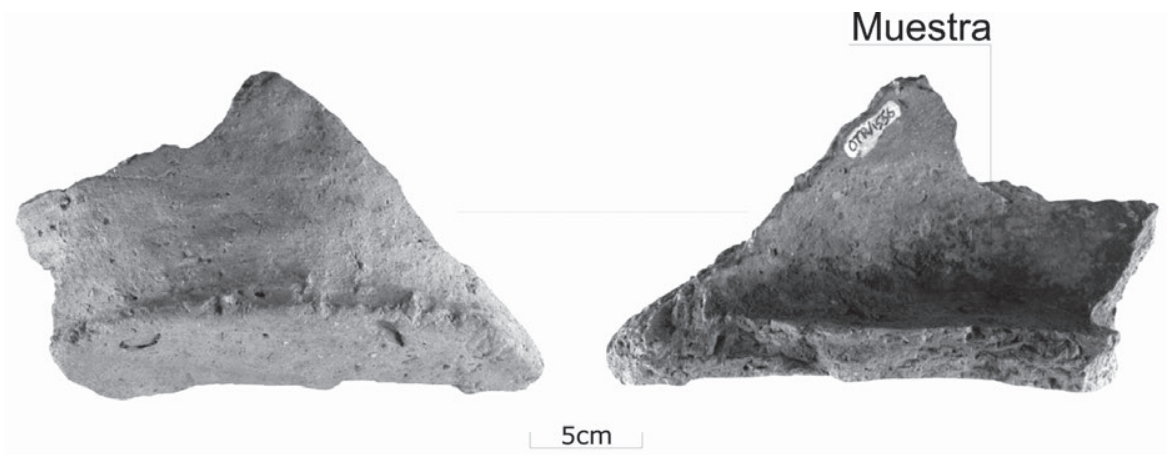

Figura 17. Fotografías del fragmento perteneciente al cacharro CAOTR027, indicando el área de procedencia de la muestra datada.

\footnotetext{
${ }^{56}$ M. Pilar Prieto Martínez, "Unity and circulation...".
} 
En OTR se documenta una fase campaniforme conformada por 61 vasijas. Al igual que en ADA se establecen tres grupos cerámicos: 44 vasijas lisas ( 10 de ellas poseen cordones superiores), 24 vasos con decoración campaniforme y 4 vasijas con decoración no-campaniforme (Figs. 18 y 19). Dentro de cada uno de estos grupos se pueden encontrar variantes, en función de las pastas y la decoración. La datación obtenida de uno de los recipientes lisos del sector aclara la cronología de la ocupación, dado que la tipología no permite precisar demasiado, pues en la región se documentan yacimientos campaniformes entre el 2800/2600 BC y el 1600/1400 BC $^{57}$.

La cerámica lisa, la más abundante, presenta un predominio de morfologías simples y perfiles cerrados, siendo mayoritarios los cuencos, sin embargo, se pueden encontrar un número significativo de morfologías compuestas cerradas con panzas globulares. Las pastas de este grupo son semejantes a las descritas para ADA en fase campaniforme, con un grupo mayoritario de acabados alisados toscos y otro minoritario de alisados medios. Los recipientes con cordones presentan unos rasgos morfotécnicos semejantes a las lisas, al igual que en ADA, si bien en OTR cabe destacar una concentración de varios recipientes rotos que podrían estar in situ, los únicos documentados en estas condiciones, como si fuese una deposición ritual.

La cerámica campaniforme es documentada en un 39,4\%, una proporción mucho mayor que en ADA. Son recipientes de morfologías compuestas, también muy fragmentados. Presentan texturas compactas finas y los desgrasantes son inapreciables tanto en superficie como en fractura. La manufactura en esta fase de fabricación es más cuidada en OTR que en ADA, respondiendo a los rasgos típicos de los campaniformes registrados en asentamientos al aire libre gallegos. Se han podido clasificar dos variantes: La primera de recipientes con una decoración simple con impresión de peine o concha (zamburiña y berberecho), motivos de líneas rectas horizontales y acabados alisados finos aunque con una pasta poco decantada. Dentro de este grupo destaca el vaso $\mathrm{n}^{\circ} 53$, decorado con impresión de concha de berberecho, que podría haber sido utilizado como vasija-horno, pues muestra las características típicas de las mismas ${ }^{58} \mathrm{y}$, además, los análisis fisicoquímicos realizados en esta pieza muestran que ha sufrido altas

\footnotetext{
${ }^{57}$ M. Pilar Prieto Martínez, "La alfarería de las comunidades...”.

${ }^{58}$ Por el momento es una hipótesis de trabajo que debemos considerar con cautela. Ver proceso en la obra de Ignacio Montero, "Sureste", en Germán Delibes de Castro e Ignacio Montero Ruiz (coords.), Las primeras etapas metalúrgicas en la Península Ibérica. II. Estudios Regionales, Madrid, Instituto Universitario Ortega y Gasset, 1999, págs. 333-357. Las vasijas horno también pueden ser denominadas vasijas de reducción, Martina RENZI, "Vasijas de uso metalúrgico, toberas y moldes" en Ignacio Montero (coord.), Manual de Arqueometalurgia, Alcalá de Henares, Museo Arqueológico Regional, Colegio Oficial de Doctores y Licenciados en Filosofía y Letras y en Ciencias, Sección Arqueología, 2010, pág. 126. En otros yacimientos del Morrazo han sido encontrados elementos
} 
EL YACIMIENTO DE A DEVESAS DE ABAIXO (PONTEVEDRA): MUERTE Y TRADICIÓN EN LA PREHISTORIA RECIENTE DEL NOROESTE DE LA PENÍNSULA IBÉRICA

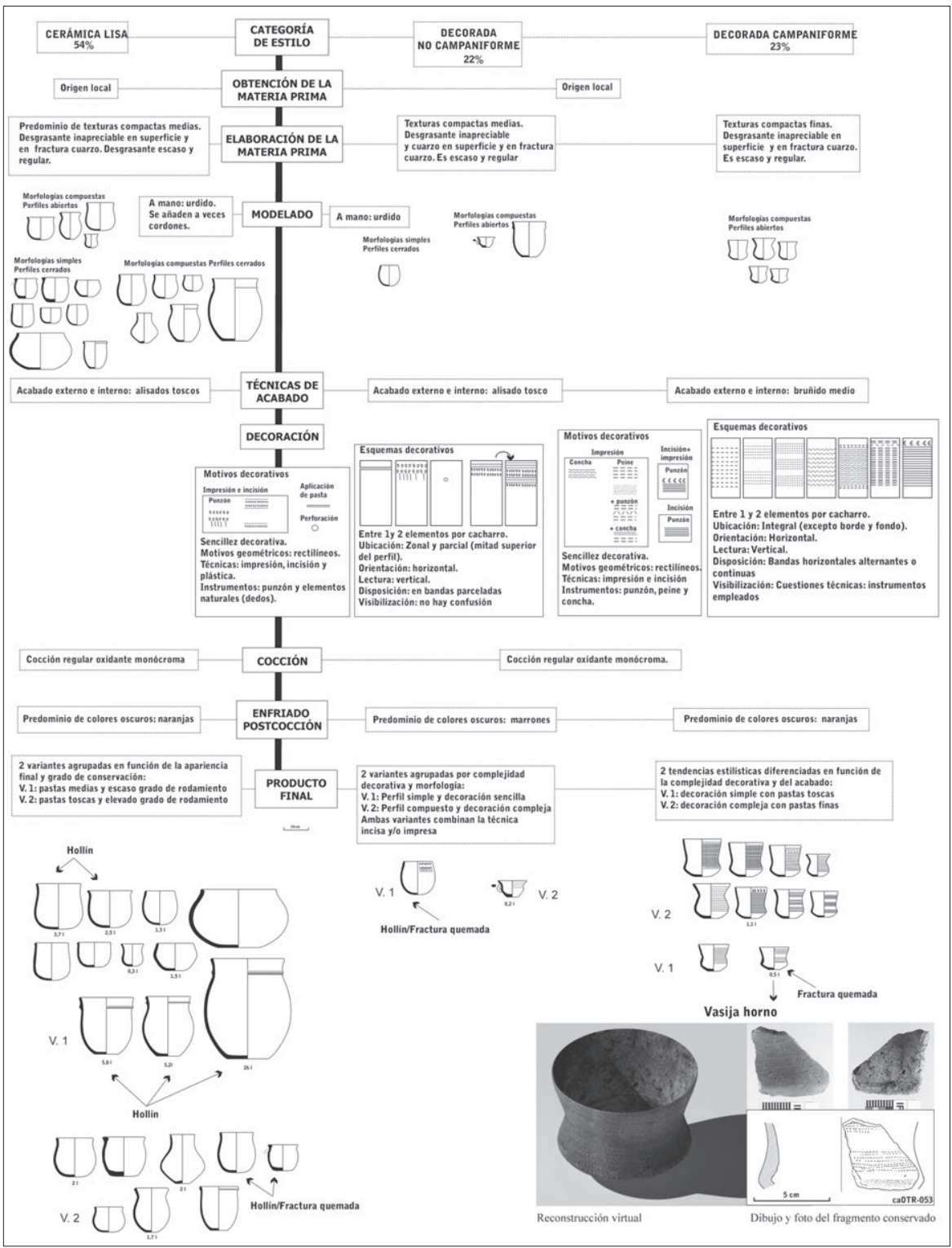

Figura 18. Cadena Esquema de la cadena operativa de OTR correspondiente al Bronce Inicial. 


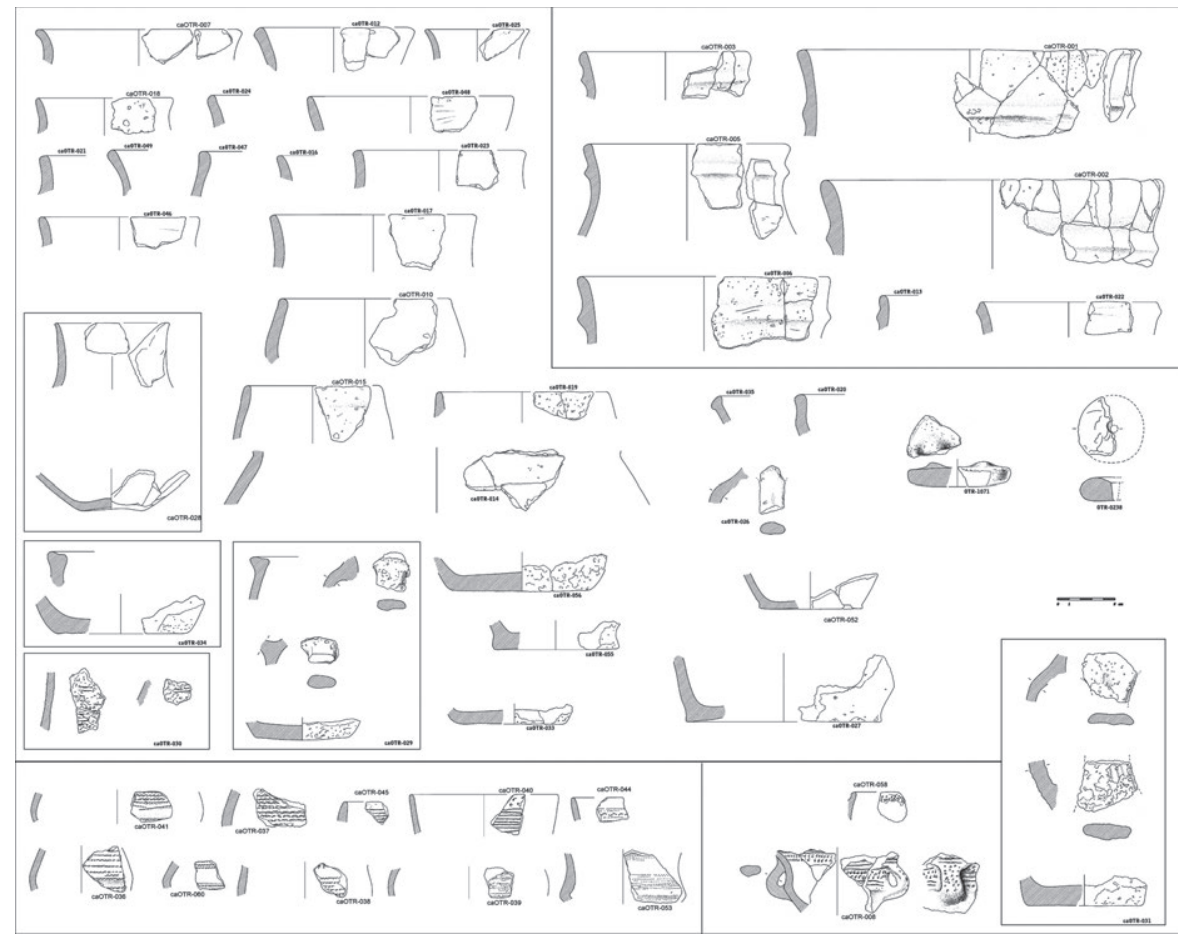

Figura 19. Dibujos de las piezas significativas de OTR (realizados por Anxo Rodríguez Paz).

temperaturas, sobrepasando $\operatorname{los} 1000^{\circ} \mathrm{C}$ pues se han identificado minerales como mullita, cristobalita y olivino ${ }^{59}$, siendo la primera vez que se detectan temperaturas de cocción (o de uso) tan elevadas en cerámicas del Bronce Inicial. Sería, por lo tanto la primera vasija-horno documentada en esta zona de Iberia. Este grupo se integraría en lo que se denomina campaniforme estándar europeo ${ }^{60}$. La segunda

que forman parte del proceso de producción de cobre y que podrían ser vinculados con el desarrollo de una metalurgia en dicha península. La última síntesis sobre ello puede consultarse en el trabajo de Beatriz Comendador Rey, "Noroeste”, en Germán Delibes de Castro e Ignacio Montero Ruíz (coords.), Las primeras etapas metalúrgicas en la Peninsula Ibérica. II. Estudios Regionales, Madrid, Instituto Ortega y Gasset, 1999, págs. 9-39.

59 Óscar LANTES SuÁrez, Análisis arqueométrico y estudio de procedencias de las cerámicas del yacimiento de la Edad del Bronce Inicial de Os Torradoiros (Moaña, Pontevedra) (RIAIdt- USC), Santiago de Compostela: Informe Inédito. Project HAR2012-34029, USC, 2014.

${ }^{60}$ Laure Salanova, La question du campaniforme en France et dans les Iles anglonormandes: productions, chronologie et rôles d'un standard céramique, Paris, coédition Société Préhistorique Française et Comité des Travaux Historiques et Scientifiques. 2000; M. Pilar Prieto Martínez, "El área arqueológica de A Lagoa...", para el caso gallego. 
variante es más numerosa y está conformada por los recipientes de mayor tamaño con una decoración más compleja, incorporando además de las líneas rectas horizontales, líneas oblicuas y zig-zags horizontales. En algunos casos se combinan varias técnicas decorativas (impresión y en menor medida incisión) y unas pastas cuidadas. Este grupo encaja en el ya conocido campaniforme regional, imitando la decoración simple de la cerámica campaniforme estándar, variante regional típica y exclusiva de Galicia ${ }^{61}$.

Finalmente, la cerámica decorada no campaniforme presenta dos variantes. La primera responde a morfologías simples cerradas, de pastas más toscas, con una decoración impresa muy sencilla, de una o dos líneas en el borde del recipiente, también encontrada en ADA. Este tipo de cerámica es todavía poco conocido en Galicia como ya comentamos para ADA, y es asociada a una datación de finales del III milenio e inicios del II milenio BC, coherente con la datación obtenida para OTR. La segunda variante, también es excepcional en Galicia, es un recipiente de perfil compuesto con un borde esvasado flexionado brusco y pastas medias, con una decoración que 'imita' la campaniforme, para el cual no encontramos paralelos regionales ni europeos.

\section{SíNTESIS E HIPÓTESIS DE LA SECUENCIA DE USO DE AdA-OTR}

La combinación de la información radiocarbónica y cerámica nos permite plantear la existencia de 7 momentos de actividad humana en ADA-OTR. La batería de dataciones disponibles para ADA (Fig. 20) evidencian el comienzo de la actividad humana en la segunda mitad del $\mathrm{V}$ milenio BC, materializado en la deposición o ruptura de vasijas sobre el afloramiento de gneis que sobresale en ciertos sectores del espolón en el que, con posterioridad, se irá conformando un yacimiento funerario de larga diacronía y complejo a nivel estructural, hecho claramente vinculado con el culto o atracción por ciertos elementos naturales conspicuos, antes del comienzo de su manipulación y transformación por las comunidades humanas posteriores.

La primera alteración humana del elemento natural o espolón constatada en el primer tercio del IV milenio BC se concreta en la preparación de una estructura de enterramiento en fosa que debió de funcionar como tumba colectiva o panteón durante un período de tiempo que no debió ser muy amplio dadas las propias características formales de la estructura, y a la que se asocian prácticas ceremoniales en forma de deposición o ruptura de vasijas cerámicas en su entorno, como continuación de la costumbre iniciada en el V milenio de ADA, como se puede comprobar en abundantes yacimientos tumulares cuando se excavan (por

\footnotetext{
${ }^{61}$ M. Pilar Prieto Martínez, "La alfarería de las comunidades...”.
} 
ejemplo, en Roza das Aveas $2^{62}$, Monte de A Romea ${ }^{63}$, As Mamelas ${ }^{64}$, Forno dos Mouros y San Cosme ${ }^{65}$, Dombate ${ }^{66}$, entre otros).

Un milenio después, en la primera mitad del III milenio BC, es acondicionada otra tumba de dimensiones más modestas en el entorno de la estructura primigenia, a la que le siguen otras estructuras no funerarias pero que en algún caso están directamente vinculadas a las tumbas. Así, se lleva a cabo la delimitación de la zona funeraria con un nivel de piedras y el sellado del mismo y de las tumbas neolíticas, con un depósito de arcilla que termina por ocultar definitivamente el lugar de ocupación de las estructuras.

Al poco de la clausura de los enterramientos en fosa es preparada una estructura de finalidad indefinida en el entorno suroccidental del yacimiento, en el segundo cuarto del III milenio y comienza la cubrición del área funeraria y entorno con una capa de piedras provenientes del afloramiento presente en distintas zonas del espolón, principalmente en el lateral nororiental, sobre la que se disponen materiales cerámicos y líticos.

Poco después, hacia mediados del III milenio BC es acondicionada una estructura de combustión en la antigua área funeraria, rompiendo el sello arcilloso y que seguramente se puede relacionar con el inicio de la actividad o reutilización campaniforme del lugar, materializada fundamentalmente en la colocación de cacharros rotos, principalmente en el entorno meridional de la necrópolis neolítica. Parte de estos recipientes, los que poseen cordones, son documentados en las primeras fases campaniformes. Pero dado que los de ADA presentan características semejantes a los hallados en OTR, también rotos in situ, quizás sea más lógico plantear que ese momento de actividad campaniforme se asocie a la propia actividad de OTR, en la transición entre el III y II milenios BC. Así, podríamos plantear que esta es la primera fase de la Edad del Bronce o campaniforme del yacimiento propiamente dicha. A pesar de no disponer de dataciones radiocarbónicas, la presencia de cerámicas campaniformes acanaladas e incisas junto a

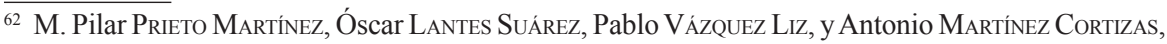
"La cerámica de dos túmulos...".

${ }^{63}$ M. Pilar Prieto Martínez, "Volviendo a un mismo lugar: recipientes y espapcios en un monumento megalítico gallego (NW de España)", Revista Portuguesa de Arqueología, 10(2) (2007), págs 101-125.

${ }^{64}$ Juan CANo PAN, "El poblado de As Mamelas...".

${ }^{65}$ M. Pilar Prieto Martínez, "Poder y estrategias de apropiación del espacio en las comunidades campaniformes. Dos casos de estudio: el dolmen de Forno dos Mouros y el túmulo 3 del Alto de San Cosme", en María Pilar Prieto Martínez y Laure Salanova (coords.), Las Comunidades Campaniformes en Galicia. Cambios sociales en el III y II milenios BC en el NW de la Península Ibérica, Pontevedra, Diputación de Pontevedra, 2011, págs. 85-94.

${ }^{66}$ Fernando Alonso Mathías Jose María Bello Diéguez, "Aportaciones del monumento de Dombate al megalitismo noroccidental; dataciones de carbono 14 y su contexto arqueológico", Trabalhos de Antropologia e Etnologia, 35 (1) (1995), págs 153-181.
} 


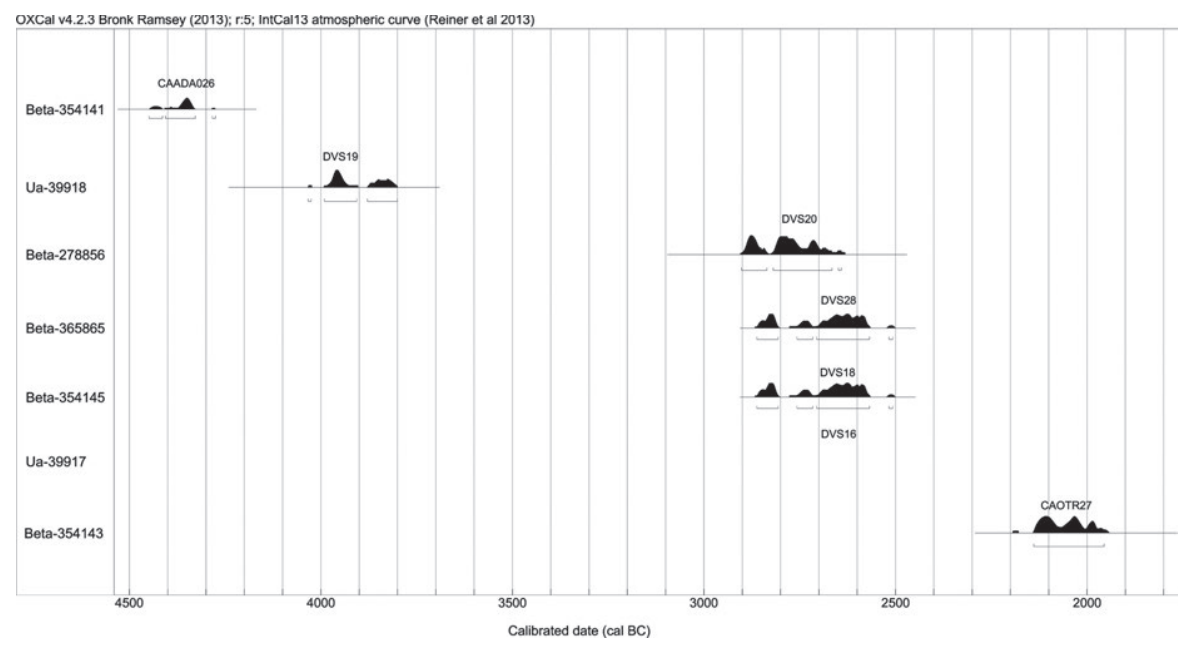

Figura 20. Cuadro de dataciones comparadas de ADA-OTR.

recipientes decorados no-campaniformes, nos habla de una posible segunda fase campaniforme, pero en un momento más avanzado, quizás próximo a mediados del II milenio.

Posteriormente, y a pesar de la falta de datos radiocarbónicos, ya en el II milenio $\mathrm{BC}$, sería erigida una pequeña cista en el entorno occidental del área funeraria, y serían depositados varios cacharros incisos sobre la capa de piedras de revestimiento del yacimiento, continuando así la tradición que se remonta a la segunda mitad del V milenio BC.

Por último, en época histórica es preparada en el área de ocupación de la necrópolis neolítica una pequeña estructura pétrea en fosa, que por sus características asemeja una caja de finalidad funeraria, rompiendo una vez más el sello arcilloso de preservación y ocultación de las tumbas neolíticas y entorno, pero sin afectar a las mismas, lo que hace suponer que el lugar de ocupación de ambas tumbas pervivió por tradición cuando menos hasta época altomedieval, aunque no podemos concretar su intensidad o significado particular.

\section{Comentarios Finales}

A lo largo de las líneas expuestas en este trabajo hemos tratado de subrayar la singularidad de un yacimiento que en el estado actual de nuestros conocimientos no tiene parangón en la región. Tal singularidad se basa tanto en su larga diacronía de uso, más de dos milenios, como en la diversidad de estructuras que lo 
integran: dos tumbas en fosa sin paralelos en todo el noroeste, dos hogares, una cista con estela y una estructura con molino central de finalidad imprecisa. Pero tampoco se limita a las estructuras, sino también al resultado final de la unión de esas arquitecturas con otros elementos constructivos, como son un nivel de piedras de delimitación, un depósito arcilloso limitado a ese espacio y que sella las estructuras en fosa neolíticas y una capa de piedra que cubre la totalidad del depósito así como su entorno.

Tal resultado final presenta ciertos paralelismos con los monumentos tumulares, en particular con los que disponen de cámara megalítica y que son objeto de reutilización a lo largo del tiempo, pues el yacimiento de ADA, en función de la disparidad de estructuras y la distinta cronología que presentan los materiales cerámicos, fue objeto de visitas por parte de grupos muy diferentes que dejaron su huella, bien acondicionando nuevas arquitecturas o bien simplemente depositando o rompiendo recipientes cerámicos (sobre unos 70), primero entorno a las tumbas en fosa y después a lo largo y ancho de la capa de piedra de revestimiento superficial, elemento este último al que también añadieron materiales líticos. A nivel estrictamente formal, ADA lo podríamos interpretar como una tumulación de desarrollo horizontal, al contrario del desarrollo eminentemente vertical que presentan los monumentos tumulares, pero tal circunstancia sólo se produce en la fase final de uso neolítico del yacimiento, cuando se clausuran los enterramientos en fosa. Dejando a un lado los túmulos reutilizados, no se conoce ningún otro tipo de yacimiento no monumental que se pueda aproximar a nivel estructural y cronológico a ADA en todo el noroeste peninsular, aspecto que acentúa aún más su originalidad y quizás nos esté mostrando que esta zona ibérica se integra en un proceso funerario de simultanear fórmulas monumentales y no monumentales generalizado en toda Europa en mayor o menor grado.

En este contexto, los enterramientos en fosa ADA06 y ADA07 parecen constituir una excepción a la norma de la época, por su convivencia con las primeras manifestaciones megalíticas en el caso de la primera y con el fin del mismo como solución mayoritaria adoptada en el interior del túmulo en el caso del segundo. El uso de fórmulas de enterramiento alternativas a los túmulos no debió alcanzar un gran desarrollo, limitándose quizás a determinados grupos o comunidades en los que se dieron las condiciones idóneas para plantear otras alternativas funerarias durante el IV y la primera mitad del III milenio BC. Incidimos en la excepcionalidad de estas soluciones en fosa más antiguas, por su escasa representatividad en el registro arqueológico del noroeste peninsular, pues como ocurre con las evidencias de las prácticas funerarias pretumulares al aire libre, apenas fueron documentadas en los trabajos de control y seguimiento arqueológico de las grandes infraestructuras lineales acometidas en los últimos 25 años en Galicia. 


\section{BIBLIOGRAFÍA}

Aboal Fernández, Roberto, Ayán Vila, Xurxo, Criado Boado, Felipe, Prieto Martínez, M. Pilar y Tabarés Domínguez, Marta, "Yacimientos sin estratigrafía: Devesa do Rei, ¿un sitio cultual de la Prehistoria Reciente y la Protohistoria de Galicia?", Trabajos de Prehistoria, 62(2) (2005), págs. 165-180.

Aboal Fernández, Roberto, Baqueiro Vidal, Sofía, Castro Hierro, Virginia, Prieto Martínez, M. Pilar y Tabarés Domínguez, Marta, "El yacimiento del III milenio BC de Zarra de Xoacín (Lalín, Pontevedra)", Lancia, 6 (2004-2005), págs. 37-58.

Acuña Piñeiro, Angel, Barbeito Pose, Víctor y Prieto Martínez, M. Pilar, "Setepías (Cambados, Pontevedra), un ejemplo de arquitectura doméstica en la Edad del Bronce", en María Pilar Prieto Martínez y Laure Salanova (coords.), Las Comunidades Campaniformes en Galicia. Cambios sociales en el III y II milenios BC en el NW de la Península Ibérica, Pontevedra, Diputación de Pontevedra, 2011, págs. 13-24.

Alday Ruiz, Alfonso, Montes Ramírez, Lourdes y Baldellou Martínez, Vicente, "Cuenca del Ebro", en Manuel A. Rojo Pena, Rafael Garrido Pena e Iñigo García Martínez de Lagrán (coords.), El Neolitico en la Península Ibérica y su Contexto Europeo, Madrid, Ediciones Cátedra, 2012, págs. 291-332.

Baptista, José Dias, “As cistas de Vila da Ponte”, Aqua Flaviae, 21 (1999), págs. 333-352.

Alonso Mathías, Fernando y Bello Diéguez, Jose María, "Aportaciones del monumento de Dombate al megalitismo noroccidental; dataciones de carbono 14 y su contexto arqueológico", Trabalhos de Antropologia e Etnologia, 35 (1) (1995), págs 153-181.

Bettencourt, Ana M.S. y Meijide Cameselle, Gonzalo, “Agro de Nogueira, Melide (A Coruña)", Gallaecia, 28 (2009), págs. 33-40.

Blanco Rotea, Rebeca y Prieto Martínez, M. Pilar, "Carballeira do Espíritu Santo: Un asentamiento aldeano de carácter familiar del Bronce Final", en M. Pilar Prieto Martínez y Felipe Criado Boado (coords.), Reconstruyendo la historia de la comarca del Ulla-Deza (Galicia, España). Escenarios arqueológicos del pasado, Madrid, Instituto de Estudos Galegos Padre Sarmiento, CSIC-Xunta de Galicia, 2010 (TAPA, 41), págs. 63-70.

Bonilla Rodríguez, Andrés, “Asentamientos prehistóricos en As Cruces/Reborica (Aranga, A Coruña)", en María Pilar Prieto Martínez y Laure Salanova (coords.), Las Comunidades Campaniformes en Galicia. Cambios sociales en el III y II milenios BC en el NW de la Península Ibérica, Pontevedra, Diputación de Pontevedra, 2011, págs. 25-30.

Bonilla Rodríguez, Andrés y César Vila, Mario, "Excavación de un posible yacimiento relacionado con los petroglifos en la zona de Chan das Pozas. Campaña de 2005", en Felipe Criado Boado, Antonio Martínez Cortizas y Marco V. García Quintela (coords.), Petroglifos, paleoambiente y paisaje. Estudios interdisciplinares del arte rupestre de Campo Lameiro, Pontevedra, Madrid, Incipit, CSIC, 2013 (TAPA, 42), págs, 124-129.

Bóveda Fernández, María José, "Proxecto de recuperación e excavación no contorno da Cista de Bicos de Lago, Abelleira, Muros (A Coruña)", en Actuacións Arqueolóxicas Ano 2008, Santiago de Compostela, Xunta de Galicia, Consellería de Cultura e Turismo, Dirección Xeral de Patrimonio Cultural, 2010, págs. 61-62.

Brandherm, Dirk, "Algunas reflexiones sobre el bronce inicial en el noroeste peninsular. La cuestión del llamado horizonte Montelavar", Cuadernos de Prehistoria y Arqueología, 33 (2007), págs. 69-90. 
Cano Pan, Juan, "El poblado de As Mamelas (Sanxenxo, Pontevedra)", en María Pilar Prieto Martínez y Laure Salanova (coords.), Las Comunidades Campaniformes en Galicia. Cambios sociales en el III y II milenios BC en el NW de la Península Ibérica, Pontevedra, Diputación de Pontevedra, 2011, págs. 193-200.

Comendador Rey, Beatriz, "Noroeste”, en Germán Delibes de Castro e Ignacio Montero Ruíz (coords.), Las primeras etapas metalúrgicas en la Península Ibérica. II. Estudios Regionales, Madrid, Instituto Ortega y Gasset, 1999, págs. 9-39.

Criado Boado, Felipe y Martínez Cortizas, Antonio, "O modelo de formación dun xacemento arqueolóxico", en Felipe Criado Boado y Elena Cabrejas Domínguez (coords.), Obras Públicas e Patrimonio: Estudo Arqueolóxico do Corredor do Morrazo, Madrid, Instituto de Estudos Galegos Padre Sarmiento, CSIC-Xunta de Galicia, 2005 (TAPA, 35), págs. 89-95.

Cruz, Domingos J. da y Huet B. Gonçalves, António A., "A necrópole de Agra das Antas (S. Paio de Antas, Esposende, Braga)”, Portugalia, NS XIX-XX (1998-1999), págs. 5-27.

Delibes De Castro, Germán y Rodríguez Colmenero, Antonio, "Una nueva necrópolis de cistas en el NW Peninsular", Letras de Deusto, 6(12) (1976), págs. 181-186.

Fabián García, José Francisco, El aspecto funerario durante el Calcolítico y los inicios de la Edad del Bronce en la Meseta Norte, Salamanca, Ediciones Universidad de Salamanca, 1995 (Estudios Históricos y Geográficos, 93).

Fábregas Valcarce, Ramón, Bonilla Rodríguez, Andrés y César Vila, Mario, Monte dos Remedios (Moaña, Pontevedra). Un asentamiento de la Prehistoria Reciente, Santiago de Compostela, Tórculo Edicións, 2007.

Fariña Busto, Francisco, Xarra Cerámica. Enxoval dunha cista da Praia da Rola (Mugueimes, Muiños), Peza do Mes, Ourense, Museo Arqueolóxico Provincial de Ourense, 2001.

Fortes, José, “A sepultura da Quinta de Água Branca (Edade do Cobre)” Portugália 2 (1906), págs. 241-252.

Gaspar, Rita, Carrondo, Joana, Nobre, Luís, Rodrigues, Zélia y Donoso, Glòria, "Espaço para a morte. O Terraço da Foz do Medal (vale do Sabor, nordeste de Portugal) durante a Idade do Bronze", Estudos do Quaternário, 10 (2014), págs. 59-72.

Gaspar, Rita, Ribeiro, Ricardo, Rebelo, Paulo, Neto, Nuno y Carvalho, Maria Luís, "Bronze Age Funerary Context in Northeast Portugal. Terraço das Laranjeiras (Sabor Valley)", en Ana M.S. Bettencourt, Beatriz Comendador Rey, Hugo Aluai Sampaio y Edite Sá (eds.), Corpos e Metais na Fachada Atlântica de Ibéria. Do Neolítico à Idade de Bronze, Braga, APEC, CITCEM, 2014, págs. 49-62.

Gianotti García, Camila y Cancela Cereijo, Cristina, "Neolitico Final: Montenegro", en Felipe Criado Boado y Elena Cabrejas Domínguez (coords.), Obras Públicas e Patrimonio: Estudo Arqueolóxico do Corredor do Morrazo, Madrid, Instituto de Estudos Galegos Padre Sarmiento, CSIC-Xunta de Galicia, 2005 (TAPA, 35), págs. 50-54.

Gianotti, Camila, Mañana Borrazás, Patricia, Criado Boado, Felipe y López Romero, Elías, "Deconstructing Neolithic Monumental Space: the Montenegro Enclosure in Galicia (Northwest Iberia)", Cambridge Archaeological Journal, 21 (2011), págs. 391-406.

Jeunesse, Christian, "Les sépultures en fosses circulaires de l'horizon 4500-3500: contribution à l'étude comparée des systèmes funéraires du Néolithique européen", en Luc Baray y Bruno Boulestin (dirs.), Morts anormaux e sépultures bizarres. Les dépôts humains en 
fosses circulaires et en silos du Néolithique à l'âge du Fer, Dijon, Éditions Universitaires de Dijon, Collection Art, Archéologie et Patrimoine, 2010, págs. 29-53.

Jorge, Susana O., “A Estação Arqueológica do Tapado da Caldeira (Baião)”, Portugália NS, I (1980), págs. 29-50.

Lantes Suárez, Oscar, Análisis arqueométrico y estudio de procedencias de las cerámicas del yacimiento de la Edad del Bronce Inicial de Os Torradoiros (Moaña, Pontevedra) (RIAIdt- USC), Santiago de Compostela, Informe Inédito. Project HAR2012-34029, USC, 2014

Lima Oliveira, Elena y Prieto Martínez, M. Pilar, La Arqueología de la Gasificación de Galicia 16: Excavación del yacimiento de Monte Buxel, Santiago de Compostela, GIArPA, 2002 (TAPA, 27).

López Cuevillas, Florentino y Lourenzo Fernández, Xoaquín, Vila de Calvos de Randin, Santiago de Compostela, Seminario de Estudios Galegos, 1930.

Martín Seijo, María, Bettencourt, Ana M.S., Abad-Vidal, Emilio y López García, Juan Carlos, "Firewood and timber exploitation during the third and second millennia BC", in A. Campar de Almeida, Ana M.S. Bettencourt, D. Moura Sérgio Monteiro-Rodrigues y M. Isabel Caetano Alves the Northwestern Iberia: wooden resources, territories and chaine opératoire, en (eds.), Environmental Changes and Human Interaction Along the Western Atlantic Edge, Coimbra, APEQ, CEGOT, CITCEM, CCT/CGUP, 2012, págs. 115-135.

Martín Seijo, María y Uzquiano Ollero, Paloma, “Análisis antracológico de estructuras de combustión neolíticas en el Noroeste peninsular: Porto dos Valos, A Gándara y Monte dos Remedios (Provincia de Pontevedra, Galicia)", en Ana M.S. Bettencourt, M. I. Caetano Alves \& Sérgio Monteiro-Rodrigues (eds.), Variações Paleoambientais e Evolução Antrópica no Quaternário do Ocidente Peninsular, Braga, APEQ-CITCEM, 2010, págs. 125-132.

Martínez Cortizas, Antonio, Costa Casais, Manuela, Ferro Vázquez, Cruz y Ferrín Prieto, Cristina, Tratamento das mostras do xacemento arqueolóxico de Devesa de Abaixo, Santiago de Compostela: Informe Final Inédito, Laboratorio de Patrimonio, Paleoambiente e Paisaxe, USC, 2006.

Meijide Cameselle, Gonzalo, "La necrópolis del Bronce Inicial del Agro de Nogueira (Piñeiro, Toques, A Coruña) en el contexto funerario de su época" en Humanitas. Estudios en Homenaxe ó Prof. Dr. Carlos Alonso del Real, Vol. 1, Santiago de Compostela, Universidade de Santiago de Compostela, 1996, págs. 215-239.

Méndez Fernández, Fidel y López Alonso, Jose, "Excavación del yacimiento de Chan das Pozas. Campaña de 2008”, en Felipe Criado Boado, Antonio Martínez Cortizas y Marco V. García Quintela (coords.), Petroglifos, paleoambiente y paisaje. Estudios interdisciplinares del arte rupestre de Campo Lameiro, Pontevedra, Madrid, Incipit, CSIC, 2013 (TAPA, 42), págs. 130-133.

Monteagudo, Luis, García Alén, Alfredo y Meijomil, Julio Lois "El hacha de Salto (Rodeiro) y las primeras hachas de tope de dos asas en Europa", El Museo de Pontevedra, XXXV (1981), págs. 117-162.

Montero, Ignacio, "Sureste”, en Germán Delibes de Castro e Ignacio Montero Ruiz (coords.), Las primeras etapas metalúrgicas en la Península Ibérica. II. Estudios Regionales, Madrid, Instituto Universitario Ortega y Gasset, 1999, págs. 333-357.

Parcero Oubiña, César, Documentación de un entorno castreño: trabajos arqueológicos en el área de Cameixa, Santiago de Compostela, GIArPA, 1997 (TAPA,1). 
Peña Santos, Antonio de la, "Las cistas de Gandón (Cangas de Morrazo, Pontevedra)", El Museo de Pontevedra, XXXIX (1985), págs. 77-94.

Peña Santos, Antonio, Rey, Manuel, "El espacio de la representación. El arte rupestre desde una perspectiva territorial", Revista de Estudos Provinciais, 10 (1993), págs. 11-50.

Prieto Martínez, M. Pilar, La Cultura Material Cerámica en la Prehistoria Reciente de Galicia: Yacimientos al Aire Libre, Santiago de Compostela, GIArPA, 2001 (TAPA, 20).

Prieto Martínez, M. Pilar, "Volviendo a un mismo lugar: recipientes y espapcios en un monumento megalítico gallego (NW de España)", Revista Portuguesa de Arqueología, 10 (2), 2007, págs 101-125.

Prieto Martínez, M. Pilar, "Bell beakers communities in Thy. The first Bronze Age society in Denmark”, Norwegian Archaeological Review, 41(2) (2008), págs. 115-158.

Prieto Martínez, M. Pilar, "From Galicia to the Iberian Peninsula: Neolithic ceramics and traditions", en Georgiu Dragos (ed.), Early farmers, Late Foragers and Ceramic traditions. On the beginning of pottery in Europe, Cambridge, Cambridge Scholars Press, 2009, págs. 116-149.

Prieto Martínez, M. Pilar, "El área arqueológica de A Lagoa. La cerámica como expresión de división social", en María Pilar Prieto Martínez y Laure Salanova (coords.), Las Comunidades Campaniformes en Galicia. Cambios sociales en el III y II milenios BC en el NW de la Península Ibérica, Pontevedra, Diputación de Pontevedra, 2011, págs. 47-59.

Prieto Martínez, M. Pilar, "La alfarería de las comunidades campaniformes en Galicia: contextos, cronologías y estilo", en María Pilar Prieto Martínez y Laure Salanova (coords.), Las Comunidades Campaniformes en Galicia. Cambios sociales en el III y II milenios BC en el NW de la Península Ibérica, Pontevedra, Diputación de Pontevedra, 2011, págs. 333-343.

Prieto Martínez, M. Pilar, "Poder y estrategias de apropiación del espacio en las comunidades campaniformes. Dos casos de estudio: el dolmen de Forno dos Mouros y el túmulo 3 del Alto de San Cosme", en María Pilar Prieto Martínez y Laure Salanova (coords.), Las Comunidades Campaniformes en Galicia. Cambios sociales en el III y II milenios BC en el NW de la Península Ibérica, Pontevedra, Diputación de Pontevedra, 2011, págs. 85-94

Prieto Martínez, M. Pilar, "Unity and circulation: what underlies the homogeneity of Galicia bell beaker ceramic style?" en M. Pilar Prieto Martínez y Laure Salanova (coords.), Current researches on Bell Beakers. Proceedings of the $15^{\text {th }}$ International Bell Beakers Conference: From Atlantic to Ural, Santiago de Compostela, Copynino-Centro de Impresión Digital, 2013, págs. 209-249.

Prieto Martínez, M. Pilar, Lantes Suárez, Oscar y Martínez Cortizas, Antonio, "Dos enterramientos de la Edad del Bronce de la provincia de Ourense", Aquae Flaviae, 41 (2009), págs. 93-105.

Prieto Martínez, M. Pilar, Martínez Cortizas, Antonio, Lantes Suárez, Óscar y Gil Agra, Dolores, "Estudio de la cerámica el yacimiento de fosas de Fraga do Zorro", Aquae Flaviae, 41 (2009), págs. 107-121.

Prieto Martínez, M. Pilar, Lantes Suarez Oscar, Vázquez Liz, Pablo, y Martínez Cortizas, Antonio, "La cerámica de dos túmulos de Roza das Aveas (Outeiro de Rei, Lugo): un estudio diacrónico del estilo y la composición”, BSAA arqueología, LXXVI (2010), págs. 27-62.

Ramil Soneira, José y Vazquez Varela, José Manuel, "Enterramiento en cista de la edad del Bronce de "O Cubillón, Xermade (Lugo)", El Museo de Pontevedra, XXXIII (1979), págs. 61-68. 
Renzi, Martina, "Vasijas de uso metalúrgico, toberas y moldes" en Ignacio Montero (coord.), Manual de Arqueometalurgia. , Alcalá de Henares, Museo Arqueológico Regional, Colegio Oficial de Doctores y Licenciados en Filosofía y Letras y en Ciencias, Sección Arqueología, 2010, págs. 123-158.

Rojo Guerra, Manuel A., Kunst, Miguel, Garrido Pena, Rafael, García Martínez-de-Lagrán, Iñigo y Morán Dauchez, Guillermo, Paisajes de la memoria: asentamientos del neolítico antiguo en el valle de Ambrona (Soria, España), Valladolid, Universidad de Valladolid, 2008 (Serie Arte y Arqueología, 23).

Rodríguez Colmenero, A., "La cultura megalítica en el Alto Bubal”, Boletín Auriense, 1 (1971), págs. 31-60.

Salanova, Laure, La question du campaniforme en France et dans les Iles anglonormandes: productions, chronologie et rôles d'un standard céramique, Paris, coédition Société Préhistorique Française et Comité des Travaux Historiques et Scientifiques, 2000.

Sampaio, Hugo Aluai, Amorim, Maria Joâo, Vilas Boas, Luciano y Braga, Ana Catarina, "Contributo para o estudo dos contextos funerários do noroeste português: o caso de estudo da Quinta do Amorim 2, Braga”, Estudos do Quaternário, 10 (2014), págs. 35-43.

Sampaio, Hugo y Bettencourt, Ana M. S., "Between the valley and the hill top. Discoursing on the spatial importance of Pego's Bronze Age necropolis, Braga (northwest of Portugal)", Estudos do Quaternário, 10 (2014), págs. 45-57.

Silva, Eduardo Jorge Lopes y Masques, José Augusto Maia, "Escavação de uma cista em Lordelo (Anha-Viana do Castelo)", Revista de História, 1 (1984), págs. 53-72.

Silva, Maria Antónia, "A cista do Gorgolão (Vila de Ponte, Montalegre)", Portugalia NS, XV (1994), págs. 137-145.

Suárez Otero, José, A Idade do Bronce en Galicia: Aspectos ceramolóxicos. O Bronce Inicial. Santiago de Compostela, Tesina de Licenciatura Inédita, Universidade de Santiago, 1986.

Tabarés Domínguez, Marta y Baqueiro Vidal Sofía, "Estudo da cultura material do xacemento de Montenegro", en Felipe Criado Boado y Elena Cabrejas Domínguez (coords.), Obras Públicas e Patrimonio: Estudo Arqueolóxico do Corredor do Morrazo, Madrid, Instituto de Estudos Galegos Padre Sarmiento, CSIC-Xunta de Galicia, 2005 (TAPA, 35), págs. 117-119.

Tabarés Domínguez, Marta y Prieto Martínez, M. Pilar, "Ceramic study of the Devesa do Rei archaeological site (Vedra, A Coruña, Spain)", in Maria Isabel Prudêncio; Maria Isabel Dias y Joâo Carlos Waerenborgh (eds.), Proceedings of the $7^{\text {th }}$ European Meeting on Ancient Ceramics- Understanding people through their pottery, Lisboa, Trabalhos de Arqueologia 42, 2005, págs. 271-276.

Vázquez Liz, Pablo, Escavación arqueolóxica do xacemento de A Devesa de AbaixoGA36029002, San Pedro de Domaio, Moaña (Pontevedra), Santiago de Compostela, Memoria Técnica inédita, Consellería de Cultura e Xuventude, Xunta de Galicia, 2004.

Vázquez Liz, Pablo, "Idade do Bronce: Devesa de Abaixo-Os Torradoiros", en Felipe Criado Boado y Elena Cabrejas Domínguez (coords.), Obras Públicas e Patrimonio: Estudo Arqueolóxico do Corredor do Morrazo, Madrid, Instituto de Estudos Galegos Padre Sarmiento, CSIC-Xunta de Galicia, 2005 (TAPA, 35), págs. 63-69.

Vázquez Liz, Pablo y Prieto Martínez, M. Pilar, "Los yacimientos de A Devesa de Abaixo y Os Torradoiros: áreas de actividad campaniforme", en María Pilar Prieto Martínez y Laure Salanova (coords.), Las Comunidades Campaniformes en Galicia. Cambios sociales en 
el III y II milenios BC en el NW de la Península Ibérica, Pontevedra, Diputación de Pontevedra, 2011, págs. 211-225.

Vázquez Varela, José Manuel, "Enterramientos en cista de la Edad del Bronce en Galicia", Pontevedra, 0 (1980a), págs. 23-40.

Vidal Lojo, Miguel, "O Fuxiño: un asentamiento de la Edad del Bronce con campaniforme", en M. Pilar Prieto Martínez y Laure Salanova (coords.), Las Comunidades Campaniformes en Galicia. Cambios sociales en el III y II milenios BC en el $N W$ de la Península Ibérica, Pontevedra, Diputación de Pontevedra, 2011, págs. 31-38.

Villa Valdés, Angel y Cabo Pérez Luis, "Depósito funerario y recinto fortificado de la Edad del Bronce en el castro del Chao Samartín: argumentos para su datación", Trabajos de Prehistoria, 60 (2) (2003), págs. 143-151. 